\title{
La acción resarcitoria contra el falso poseedor en el derecho chileno*
}

\section{Jaime Alcalde Silva*}

RESUMEN. Este trabajo analiza la acción de indemnización de perjuicios que el reivindicador puede intentar contra el demandado que, de mala fe, se da por poseedor de la cosa sin serlo, y que el código civil chileno trata en el artículo 897. Ella reviste interés porque viene recogida como un supuesto de protección meramente obligacional a favor del dueño, habiéndose desprendido de la asimilación a la acción reivindicatoria que se había producido en el derecho romano posclásico, y queda conectada con el deber que tiene el mero tenedor de indicar el nombre y la residencia del poseedor para que el juicio continúe contra él. Esta configuración exige considerar en particular la historia legislativa de la regla en el código civil chileno, así como su correspondencia con otros códigos que la han conservado, para después diseccionar su supuesto de hecho y consecuencias jurídicas, con especial atención a los problemas que su ejercicio puede entrañar en lo que atañe a la compatibilidad con otras acciones, la prescripción y el daño resarcible.

* Fecha de recepción: 23 de marzo de 2019. Fecha de aceptación: 14 de agosto de 2020.

Para citar el artículo: AlCALDE SiLVA, J., "La acción resarcitoria contra el falso poseedor en el derecho chileno", Revista de Derecho Privado, Universidad Externado de Colombia, n. ${ }^{\circ}$ 40, enero-junio 2021, 237-269, DOI: https://doi.org/10.18601/01234366.n40.09.

Este artículo hace parte del Proyecto FONDECYT de Iniciación n. ${ }^{\circ} 11160615$, del cual el autor es investigador responsable. Las ideas que ahora se desarrollan fueron expuestas originalmente en la ponencia leída el 27 de noviembre de 2018 en las III Jornadas Internacionales de Derecho Civil Patrimonial, celebradas en Santiago y organizadas por la Pontificia Universidad Católica de Chile. El autor agradece a Emiliano Cuccia (Universidad Nacional de Cuyo-CONICET) por la ayuda prestada con la traducción al castellano del texto latino indicado en la nota 14.

** Pontificia Universidad Católica de Chile, Santiago de Chile, Chile; profesor asociado de Derecho Privado. Licenciado en Derecho, Pontificia Universidad Católica de Chile, Santiago de Chile, Chile. Doctor en Derecho, Universidad de Valencia, Valencia, España. Contacto: jcalcald@uc.cl Orcid: 0000-0003-4732-5585. 
Palabras Clave: resarcimiento del daño, mala fe, acción reivindicatoria, protección obligacional de la propiedad.

\section{The Claim for Damages against the False Possessor in the Chilean Law}

Abstract. This paper analyses the action for damages that the claimant may try against the defendant that, in bad faith, states to be a possessor without being so, and that the Chilean Civil Code regulates in its article 897. This case is interesting because it is ruled as a protection for the owner to be compensated, detaching from the assimilation to an action for the recovery of the possession as it was construed in the post-classic Roman law, and that is connected with the mere holder's duty to indicate the name and residence of the possessor so that the trial may continue against him. This configuration requires paying attention to the legislative history of the rule in the Chilean Civil Code and its correspondence with other codes that have maintained it, to then dissect the description of the factual assumption and the legal consequences of that rule, with special attention to the problems that its exercise may entail in terms of the compatibility with other actions, with its statute of limitations and the compensable damage.

KEYWORDS: compensation for damages, bad faith, action for the recovery of the possession, ownership protection by means of damages.

SumARIo. Introducción. I. Historia legislativa. II. El supuesto de hecho. III. Las consecuencias jurídicas. Conclusiones. Referencias.

\section{Introducción}

Dentro de las normas sobre reivindicación, el código civil chileno contiene una acción contra el que, de mala fe, se da por poseedor de la cosa sin serlo, para que sea condenado a indemnizar todo perjuicio que de ese engaño se haya seguido al actor (art. 897 c.c. $)^{1}$. Al menos en apariencia, este comporta uno de los supuestos previstos por el código y relativo a la cuestión de "contra quién se puede reivindicar" (libro II, título XII, § 3), de suerte que cabría asignarle la calidad de acción reivindicatoria o de dominio.

La tesis que aquí se sostiene es que, a diferencia de lo que ocurre en otros casos del mismo título, esa acción no es propiamente un supuesto de reivindicación, aunque el código civil la haya incluido dentro de esa disciplina con el propósito de cerrar

1 Las reglas contenidas en el título XII del libro II del código civil colombiano (arts. 946-971) son idénticas a aquellas del título XII del libro II del código civil chileno (arts. 889-915), donde viene tratada la reivindicación. Todas las referencias al código civil se refieren al chileno, a menos que se indique lo contrario, y lo mismo ocurre con los demás textos legales mencionados. 
(ahora en clave obligacional) los contornos de la protección dispensada al dueño, pues comporta solo un caso peculiar de pretensión resarcitoria. La conclusión que se quiere demostrar consiste en que Bello llevó a cabo una interesante operación dentro del proceso codificador ${ }^{2}$, la cual consistió en dar el carácter de una acción indemnizatoria a una situación que el derecho romano y el derecho común habían concebido como un caso asimilado por ficción a la reivindicación. Para cumplir el objetivo propuesto, en este trabajo se hace un recuento de la historia legislativa de la acción recogida en el artículo 897 c.c. (I) y, enseguida, se analizan su supuesto de hecho (II) y sus consecuencias jurídicas (III), para acabar con las conclusiones de rigor.

Cumple advertir que se trata de una regla de carácter idiosincrático, pues no es compartida por otros sistemas jurídicos. La razón es la diferente configuración que tiene la acción reivindicatoria en el derecho chileno frente a la técnica comparada que existe para proteger al dueño, donde aquella se caracteriza por una "extrema simplicidad"3 y se puede dirigir contra cualquiera que detente materialmente una cosa que no le pertenece ${ }^{4}$. Como fuere, la jurisprudencia chilena ha desempeñado una función creativa y ha venido avanzando desde hace algún tiempo en difuminar los rígidos presupuestos con que el código civil trata esta acción ${ }^{5}$. Para este último, la reivindicación (que se mienta como sinónimo de acción de dominio) supone un conflicto entre el dueño de una cosa singular de la que no está en posesión y el poseedor de ella (arts. 889,893 y 895 c.c.), de suerte que la tutela que se solicita al tribunal consiste en la restitución material de dicha cosa (art. 904 c.c.), en la medida en que ella sea reivindicable (arts. 890,891 y 892 c.c.) ${ }^{6}$. Eso explica que la legitimación en

2 Guzmán Brito, A., Andrés Bello codificador. Historia de la fijación y codificación del derecho civil en Chile, Santiago, Universidad de Chile, 1982, 432-454, analiza las diversas operaciones practicadas por Bello durante el proceso codificador.

3 Sciumè, A., s.v. "Rivendicazione (dir. intermedio)", en Enciclopedia del diritto, XLI, Milano, Giuffrè, $1989,44$.

4 Peñailillo Arévalo, D., "Expansiones y restricciones de la reivindicación en el derecho contemporáneo", en CÉSPEDES, C. (coord.), Estudios de derecho patrimonial, Santiago, Thomson Reuters, 2013, 47-55, y Peñailillo Arévalo, D., Los bienes. La propiedad y otros derechos reales, 2. ed., Santiago, Thomson Reuters, 2019, 1467-1470.

5 En la jurisprudencia sistematizada en FiguEROA YÁÑEZ, G. (coord.), Repertorio de legislación y jurisprudencia chilenas. Código civil y leyes complementarias, III, 3. a ed., Santiago, Jurídica de Chile, 1996, 355-356, que permite tener una idea general sobre el estado de la discusión hasta fines del siglo $\mathrm{xx}$, se señala que los tribunales tenían asentada la idea de que no podía acogerse una demanda de reivindicación cuando el demandado era solo poseedor material de la cosa y carecía de la posesión efectiva del artículo 696 c.c., que únicamente se adquiere merced a una inscripción conservatoria. Pero la situación comenzó paulatinamente a cambiar. Solo veinte años después, BARRIENTOS Grandon, J., El código civil. Su jurisprudencia e historia. Edición crítica, concordada, comentada y anotada, I, Santiago, Thomson Reuters, 2016, 1038, reporta que la jurisprudencia mayoritaria se inclina por acoger la acción reivindicatoria cuando el demandante ocupa el bien como señor y dueño pero carece de respaldo registral.

6 Resulta de interés que el artículo 889 c.c. equipare reivindicación y acción de dominio, puesto que el artículo 577 II c.c. señala que de los derechos reales nacen las acciones que tienen ese carácter. Esto significa que, siendo la reivindicación la acción correspondiente a la propiedad, debe cubrir todos los casos en que el dueño ve afectada su titularidad desde una perspectiva que suponga su descono- 
este juicio corresponda respectivamente al dueño, sea que tenga la propiedad plena o nuda, absoluta o fiduciaria de la cosa (art. 893 c.c.), y al poseedor regular que se hallaba en el caso de poder ganarla por prescripción (art. 894 c.c.) ${ }^{7}$. De ahí se sigue que el sistema elegido por el código chileno requiera de ciertas reglas de clausura relativas al correcto emplazamiento del demandado (art. 896 c.c.), la imposibilidad de perseguir la cosa (arts. 898 y 900 c.c.) o la frustración de la acción por ausencia de legitimación pasiva (arts. 897 y 915 c.c.). Con todo, en el supuesto que ahora interesa, el código civil se ha guardado de calificar la acción que se concede al demandante como una hipótesis de reivindicación, a diferencia de lo que ocurre en otros supuestos del título XII del libro II (arts. 898, 900 y 915 c.c.), y era el origen histórico de la regla. La razón es que se trata de un supuesto especial de responsabilidad extracontractual, fundado en el engaño del falso poseedor.

\section{Historia legislativa}

Como antecedente inmediato, el artículo 897 c.c. aparece impreso por primera vez en el Proyecto de 1853 (art. 1043) ${ }^{8}$. Pero la regla tenía ahí una formulación distinta, porque distinguía dos situaciones: (i) una para quien se daba como poseedor de la cosa y (ii) otra para el que tenía ese comportamiento movido por su mala fe. El primero solo venía obligado al pago de las costas judiciales en que hubiese incurrido el actor a consecuencia de ese falso concepto, mientras que el segundo había de ser condenado al resarcimiento de todo perjuicio que aquél hubiese sufrido. Desde el Proyecto Inédito, vale decir, tras el primer examen al que fue sometido el Proyecto de 1853 por parte de la Comisión Revisora, la regla que se comenta tuvo ya la redacción con que hoy se lee (art. 1043) ${ }^{9}$. La única diferencia era que el Proyecto aproba-

cimiento y no solo la pérdida o conservación de su detentación, pues a esa función se ordenan las acciones posesorias (arts. 926 y 928 c.c.).

7 Coing, H., Derecho privado europeo, A. Pérez Martín (trad.), Madrid, Fundación Cultural del Notariado, 1996, II, 483, y ScIumè, s.v. "Rivendicazione (dir. intermedio)", cit. 46-47, señalan que, en la mayoría de los países, la acción publiciana fue suprimida o muy discutida su pervivencia (véase, sobre su origen, infra, nota 24). Por ejemplo, el derecho alemán y suizo no la conocen, y lo mismo se concluye para el derecho francés e italiano. Sí existió en la zona del derecho común y predomina la idea de que también se la aceptó en Austria bajo la forma de una acción restitutoria de mejor posesión (\$ $372 \mathrm{ABGB}$ ). Bello optó por conservar esta acción en el artículo 895 c.c., sirviéndose de fuentes romanas y de Pothier. Cfr. Amunátegui Perelló, C., Código civil de Chile. Edición anotada, concordada y con fuentes, Valencia, Tirant lo Blanch, 2019, 248; BARrientos, El código civil, I, cit., 1035-1037, y Schiele Manzor, C., “Artículo 894 del código civil: ¿prueba de mejor derecho?”, en Domínguez Hidalgo, C. (ed.), Estudios sobre propiedad y posesión. Perspectiva chilena y latinoamericana, Santiago, Thomson Reuters, 2019, 83-104. Véase un amplio desarrollo de esta acción y su recepción en Cuesta SAEnz, J., La acción publiciana, Madrid, Montecorvo, 1984, 125-244 (derecho intermedio y preludio de la codificación), 245-300 (derecho comparado) y 301-446 (derecho español, donde no está recogida expresamente).

8 Bello, A., Código civil de República de Chile, i, Caracas, Ministerio de Educación, 1954, 578.

9 Dicha Comisión era presidida por el propio presidente de la República, Manuel Montt, y estaba integrada por Andrés Bello, Manuel José Cerda y Ramón Irarrázaval, estos dos últimos ministros de 
do por el Congreso el 14 de diciembre de 1855 cometía un error semántico, el que fue solucionado al acometerse la revisión previa a la impresión del texto definitivo de la edición príncipe durante el mes de abril de 1856: aquella versión decía que la acción se dirigía respecto del que "se da por poseedor de la cosa que reivindica", en vez de quien "se da por poseedor de la cosa que se reivindica", diferencia que alteraba el sentido en cuanto al sujeto pasivo de dicha pretensión ${ }^{10}$.

Con todo, la redacción de la regla es anterior y se encuentra ya en el borrador manuscrito del originario "Título 9. De la reivindicación”, compuesto por Bello después de agosto de $1847^{[11]}$. El artículo 13 de ese manuscrito pasó al mentado artículo 1043 del Proyecto de 1853, con la sola eliminación de la redundancia que se producía al decir "la completa indemnización de todo perjuicio" contenida en el primero. Aunque tanto en ese primer cuaderno como en las sucesivas versiones la regla carece de notas sobre su fuente, Barrientos estima que el origen se encuentra en el siguiente comentario recogido por Pothier (1699-1772) en su versión de las Pandectae (lib. VI, tít. I, sec. II, XVII ${ }^{12}$ :

Item Is qui se obtulit rei defensioni sine causa, cum non possideret nec dolo fecisset quominus possideret, si actor ignoret, non est absolvendus; ut Marcellus ait. Quae sententia vera est.
Además, [e]l que sin causa se presentó a la defensa de una cosa, no poseyéndola, ni habiendo hecho con dolo de modo que no la poseyera, si el actor lo ignorase, no ha de ser absuelto, como dice Marcelo, cuya opinión es verdadera [Dig. 6, 1, 25].

la Corte Suprema; Diego Arriarán, Antonio García Reyes y Manuel Antonio Tocornal, todos miembros de la Facultad de Leyes de la Universidad de Chile; Alejo Valenzuela, ministro de la Corte de Apelaciones de Santiago; José Gabriel Ocampo, años después decano de aquella Facultad, y José Miguel Barriga, ministro de la Corte de Apelaciones de Concepción. Andrés Bello, Antonio García Reyes y José Gabriel Ocampo formaban parte de la comisión por tener el encargo de preparar algún otro código: Bello, el código de procedimientos civiles, García Reyes, el código penal, y Ocampo, el código de comercio. No existe mucha información sobre el trabajo llevado a cabo por la Comisión, que fue constituida por decreto supremo del 26 de octubre de 1852, pues no se levantaron actas oficiales de sus más de trescientas sesiones. Sí hay constancia de algunas notas privadas tomadas por el propio Bello, que actuaba como secretario. Sin embargo, de ellas no queda más que un testimonio indirecto y referido solo a cuatro artículos del título preliminar. Véase Amunátegui Reyes, M., "Introducción”, en Bello LóPez, A., Obras completas, XIII, Santiago, Pedro G. Ramírez, XL-XLIII; GuZmán Brito, Andrés Bello codificador. Historia de la fijación y codificación del derecho civil en Chile, cit., I, 369-378; SAlinas ArAnEda, C., "Notas en torno a las actas de los proyectos de código civil chileno", Revista de Derecho de la Pontificia Universidad Católica de Valparaíso, n. ${ }^{\circ} 1,1977$, 33-41.

10 El uso de la forma reflexiva resulta indispensable para asegurar la alteridad de la regla.

11 BARrientos, El código civil, I, cit., 1020-1021 y 1040.

12 Ibíd., 1040-1041. 
Sed hoc post litem contestatam. Caeterum ante judicium acceptum non decipit actorem, qui se negat possidere cum vere non possideret; nec videtur se liti obtulisse, qui discessit. l. 25. Ulp. Lib. 70 ad Ed.

Uno tamen casu impune non discedet. Enimvero: Sin autem cum a Titio petere velim, aliquis dixerit se possidere, et ideo liti se obtulit; et hoc ipsum in re agenda testatione probavero; omnimodo condemnandus est. $l$. 27. Paul. Lib. 21. ad Ed.

Ita demum autem damnatur qui se liti obtulie, si actor ignorabat cum non possidere. Nam si actor scit, tunc is non ab alio, sed a se decipitur; et ideo reus absolvitur. l.26. Paul. Lib. 2. Ad Plautium.

Illud superest observandum quod $\mathrm{Si}$ is qui obtulit se fundi vindicationi, damnatus est; nihilominus a possessore recte petitur: sicut Pedius ait. l. 7. Paul Lib. II. ad Edict. ${ }^{13}$.
Pero esto, después de contestada la demanda; porque antes de aceptado el juicio no engaña al actor el que niega que posee, cuando verdaderamente no poseyera; y tampoco se considera que se opuso en un litigio el que se apartó de él [Dig. 6, 1, 25].

Sin embargo, uno no se aparta impunemente del juicio. Sin duda alguna, [s]i cuando yo quisiere pedir una cosa a Ticio, dijere alguno que él la poseía, y por esto se mostró parte contraria en el pleito, si yo justificare esto mismo en la prueba al proseguir el pleito, debe ser de todos modos condenado [Dig. 6, 1,27 , pr.].

Pero sólo es responsable quien se ofrece al juicio, si el actor ignoraba que éste no estaba en posesión. Pues si el actor tiene conocimiento, entonces él no es engañado por otro, sino por sí mismo; y por este motivo es absuelto el demandado [Dig. 6, 1, 26].

Aquello queda [demostrado] observando que [s]i el que se opuso a la reivindicación del fundo fue condenado, no obstante se reclama debidamente al poseedor, según dice Pedio [Dig. 6, 1, 7] ${ }^{14}$.

Con mayor seguridad, y pese a la importancia de las Pandectae ${ }^{15}$, Bello debe haber acudido al Traité du droit du domaine de propriété de ese mismo autor, que tuvo una función importante tanto en la sistematización del título sobre la reivindicación como en su contenido y forma, y que Dalmacio Vélez Sarsfield (1800-1875) indicaba como fuente de los artículos 2784 y 2785 del código civil argentino de 1869, equivalentes a los artículos 897 y 900 c.c. ${ }^{16}$. De hecho, en el número 301 de esa obra

13 Pothier, R., Pandectae Justinianeae in novum ordinem Digestae, I, nueva ed., Lyon, Bernuset et Cie., $1782,216$.

14 La traducción al castellano de este texto ha sido hecha por Emiliano Cuccia (Universidad Nacional de Cuyo-CONICET) y revisada por el autor teniendo a la vista dos versiones del Digesto: aquella incluida en el Cuerpo de derecho civil romano (trad. de Idelfonso García del Corral, Barcelona, Jaime Molinas, 1889-1898) y la publicada separadamente con el título de El Digesto de Justiniano (trad. de Á. d'Ors et al., Pamplona, Aranzadi, 1968-1976).

15 Sciumè, s.v. "Rivendicazione (dir. intermedio)", cit., 43, califica esta obra como un "cospicuo intervento sistematico [...] sul terreno della proprietà e dei diritti reali".

16 Jestaz, P. y Jamin, C., La doctrina, P. Dufeu A. y D. Ejsmentewicz C. (trads.), Santiago, Rubicón, 2018, 95, destacan que el gran mérito de Pothier consistió en lograr "una síntesis casi perfecta de todos los esfuerzos realizados en vista de la unificación del derecho francés". 
se trata el caso del demandado que, sin poseer la finca reclamada, contesta la demanda y prosigue el juicio, guardándose una estructura equivalente a la observada en el manuscrito original del título sobre reivindicación y en el Proyecto de 1853, como se evidencia de la siguiente comparación:

\begin{tabular}{|c|c|c|}
\hline $\begin{array}{c}\text { Traité du droit du domaine } \\
\text { de propriété }\end{array}$ & $\begin{array}{l}\text { Tratado del derecho de } \\
\text { dominio de la propiedad }\end{array}$ & $\begin{array}{l}\text { Artículo } 1043 \text { del Proyecto } \\
\text { de } 1853\end{array}$ \\
\hline $\begin{array}{l}\text { Lorsque le défendeur, } \\
\text { quoiqu'il ne possédât pas } \\
\text { l'héritage pour lequel il } \\
\text { était assigné en revendica- } \\
\text { tion, a néanmoins contesté } \\
\text { et soutenu le procès, comme } \\
\text { s'il en étoit [était] le pos- } \\
\text { sesseur; si c'est par erreur, } \\
\text { croyant être assigné pour } \\
\text { un autre héritage que celui } \\
\text { pour lequel il étoit [était] } \\
\text { assigné,l'erreur étant depuis } \\
\text { découverte, il ne doit être } \\
\text { condamne qu'aux dépends; } \\
\text { mais s'il étoit [était] prouvé } \\
\text { que ce fût par malice, pour } \\
\text { empêcher le demandeur } \\
\text { de connoître [connaitre] le } \\
\text { véritable possesseur, et de } \\
\text { donner la demande contre } \\
\text { lui, afin que parce moyen le } \\
\text { possesseur pût accomplir le } \\
\text { temps de la prescription; le } \\
\text { défendeur devroit [devrait] } \\
\text { être en ce cas condamné } \\
\text { aux dommages et intérêts } \\
\text { du demandeur, qui par cette } \\
\text { fraude auroit [aurait] perdu } \\
\text { la propriété de son héritage, } \\
\text { faute d'avoir pu interrompre } \\
\text { le temps de la prescription } \\
\text { contre celui qui le possédoit } \\
\text { [possédait] } 17 \text {. }\end{array}$ & $\begin{array}{l}\text { Cuando el demandado, aun- } \\
\text { que no poseyera la finca por } \\
\text { la cual ha sido emplazado } \\
\text { en reivindicación, ha sin } \\
\text { embargo contestado y soste- } \\
\text { nido la causa, lo mismo que } \\
\text { si fuera poseedor; si es por } \\
\text { error, creyendo haber sido } \\
\text { emplazado por otra finca } \\
\text { diferente, el error quedan- } \\
\text { do después al descubierto, } \\
\text { sólo puede ser condenado al } \\
\text { pago de las costas; pero si se } \\
\text { justificara haber procedido } \\
\text { con malicia, para impedir } \\
\text { que el demandante venga } \\
\text { en conocimiento del verda- } \\
\text { dero poseedor, con el objeto } \\
\text { también de lograr se entable } \\
\text { demanda contra él, para que, } \\
\text { con este medio, pueda el po- } \\
\text { seedor terminar el tiempo de } \\
\text { prescripción, en este caso, el } \\
\text { demandado debe estar con- } \\
\text { denado a pagar los daños y } \\
\text { perjuicios al demandante, } \\
\text { quien, por este fraude, hu- } \\
\text { biera perdido la propiedad } \\
\text { de su finca, por no haber } \\
\text { podido interrumpir el tiempo } \\
\text { de la prescripción contra el } \\
\text { que la poseía } 18 \text {. }\end{array}$ & $\begin{array}{l}\text { Si alguien se da por posee- } \\
\text { dor de la cosa que se reivin- } \\
\text { dica sin serlo, será obligado } \\
\text { a pagar las costas judiciales } \\
\text { en que haya incurrido el ac- } \\
\text { tor a consecuencia de este } \\
\text { falso concepto; pero, si el } \\
\text { que se ha dado por poseedor } \\
\text { ha procedido en ello de mala } \\
\text { fe, será condenado a la in- } \\
\text { demnización de todo perjui- } \\
\text { cio que de este engaño haya } \\
\text { resultado al actor. }\end{array}$ \\
\hline
\end{tabular}

17 Pothier, R., Traité du droit du domaine de propriété, I, n. ${ }^{\circ}$ 301, Paris, Orleans, Debure, Veuve Rouzeau-Montaut, 1782, 296.

18 Pothier, R., Tratado del derecho de dominio de la propiedad, Manuel Deó (trad.), Madrid y Barcelona, Librería de V. Suárez-Librería de J. Llordachs, 1882, n. ㅇ 301, 219. 
En rigor, esta acción descrita por Pothier proviene del derecho romano posclásico, que introdujo algunas reformas importantes en el régimen de la reivindicación (rei vindicatio $)^{19}$. Una de esas innovaciones fue que dicha acción se hizo posible no solo contra el efectivo poseedor, como ocurría hasta entonces, sino también contra los llamados "poseedores ficticios" (ficti possesores). Esa calidad correspondía al que, sin ser poseedor, se hacía pasar por tal, por haberse ofrecido al verdadero poseedor (qui liti se optulit quasi possideret), con el propósito de distraer al dueño con un proceso en vano, y así permitir que aquel ganase la cosa por usucapión (Dig. 6, 1, 27 , pr.; $6,1,25 ; 6,1,52 ; 7,6,6)^{20}$. En el derecho clásico, esta figura era igualmente posible, pero el poseedor ficticio no estaba legitimado pasivamente dentro del esquema de la reivindicación. El asunto quedaba resguardado por la cláusula de dolo de la cautio iudactum solvi que todo demandado debía ofrecer al comenzar el juicio: una vez comprobado que ese demandado no era el verdadero poseedor, sino una persona interpuesta, su dolo quedaba al descubierto y sujeto a la actio ex stipulatu, con las mismas consecuencias que el demandado que no asumía la defensa en juicio, vale decir, debía acatar la orden del pretor de entregar la posesión de la cosa al actor si se encontraba en su poder (Dig. 2, 3, 1, 1) ${ }^{21}$.

A diferencia de los ordenamientos modernos que se fundan en los derechos subjetivos, el derecho romano configuraba su sistema de tutela sobre la base de un esquema de acciones típicas ${ }^{22}$. Esto significaba que las posibilidades de reclamación en juicio tenían que ver con la existencia de una acción que recogía en la descripción de su fórmula la situación concreta que afectaba al demandante. En el caso de la acción reivindicatoria, aquella solo hacía mención de la legitimación activa: "si la cosa de la cual se trata resulta ser de" quien la demanda (Dig. 6, 1; Cod. 3, 32). Como en ella no se decía nada respecto de la calidad del demandado, la jurisprudencia disputó el asunto, pero predominó la idea de que la acción se dirigía contra el que poseyese actualmente la cosa al momento de la litis contestatio ${ }^{23}$. La situación cambió a partir de una constitución de Constantino de 331, cuando se impuso al demandado detentador de la cosa objeto del litigio el deber de declarar la identidad de la persona por la cual estaba poseyendo (nominatio auctoris), para darle traslado de la demanda: si esta acudía al juicio, el mero tenedor quedaba excluido de sus resultas; mientras

19 Amunátegui, Código civil de Chile, cit., 248, señala que la fuente del artículo 897 c.c. es en realidad el número 306 del Traité du droit du domaine de propriété de Pothier, pero ese caso se refiere al supuesto del artículo 900 c.c.: el del poseedor que por malicia deja de poseer para sustraerse de la acción.

20 El otro caso es aquel que trata el artículo 900 c.c., vale decir, el del poseedor de mala fe que procura deshacerse de la cosa para hacer imposible la reivindicación (Dig. 6, 1, 27, 3; 6, 1, 36, pr.).

21 Guzmán Brito, A., Derecho privado romano, i, Santiago, Jurídica de Chile, 1996, 471.

22 Véase, p. ej., GuzMán Brito, A., "Dialéctica, casuística y sistemática en la jurisprudencia romana", Revista de Estudios Histórico-Jurídicos, n. ${ }^{\circ}$ 5, 1980, 17-31.

23 GuZMán Brito, Derecho privado romano, cit., I, 466-467. 
que si no llegaba a comparecer, el magistrado ordenaba la entrega de la cosa al actor (Cod. 3, 19, 2).

Pero hay que tener en cuenta que la reivindicación romana tenía una diferencia significativa con la acción que hoy se mienta con ese nombre. Si el demandante lograba probar su derecho, y si el demandado no se allanaba voluntariamente a la restitución (Gai. 4, 163), este último venía condenado a cuanto la cosa valía al momento de la sentencia (quanti ea res erit), de acuerdo con la valoración hecha por el juez (litis aestimatio) o por el actor a invitación de este (iusiurandum in litem). De ello se seguía que el demandado mantenía para sí la posesión de la cosa que comenzaba a ser considerada como comprada merced al pago de la condena que le había sido impuesta. Esto significaba que la poseía en adelante pro emptore, como comprador (Dig. 6, 1, 46; 6, 1, 70; 6, 2, 7, 1; 25, 2, 22, pr.; 41, 4, 1; 41, 4, 3), y la podía adquirir por la consiguiente usucapión, quedando protegido entretanto con la actio Publiciana ${ }^{24}$. Solo con la introducción del procedimiento extraordinario bajo Diocleciano (294 d.C.) fue posible obtener la restitución forzada de la cosa, sin dejar la alternativa sobre el modo de cumplimiento de la sentencia en manos del demandado (de ahí la hábil interpolación de Dig. $6,1,68)^{25}$, característica que posteriormente se asienta en el derecho común ${ }^{26}$. Por el contrario, en el derecho moderno el carácter restitutorio es inherente a la reivindicación: ella está destinada a que el demandado restituya la cosa misma que se ha demandado dentro del plazo fijado por la sentencia (art. 904 c.c.), lo que explica la tendencia expansiva antes apuntada de concederla contra quien detenta la cosa y no solo contra el que sea formalmente su poseedor ${ }^{27}$.

La configuración de la reivindicación durante el derecho común no presenta mayores innovaciones y siguió de cerca, con algunos desarrollos, las reglas asentadas en el derecho justinianeo, incluido el caso recogido en Dig. 6, 1, 9 del que posee como detentador a nombre de otro y se puede liberar mediante la designación de la

24 El ejercicio de la rei vindicatio no estaba previsto en el derecho romano para el poseedor que no era dueño y dejó de poseer, quien debía esperar el cumplimiento de los plazos de usucapión para ser considerado poseedor civil y poder así servirse de la acción reivindicatoria. En el siglo I a.C. se introdujo una acción especial destinada a subsanar ese estado de indefensión, la que se conoce como actio Publiciana, quizá porque provino del pretor del año 67 Quinto Publicio. Dicha acción se concedía (i) al adquirente de una res mancipi respecto de la cual se había omitido un modo solemne de adquirir (mancipatio o in iure cessio), y (ii) al que recibió por una tradición no dominical cualquier cosa identificable, sin importar si hubo un modo solemne de adquirir tratándose de una res manicipi. En otras palabras, era una acción que podía ser ejercida por quien adquirió la posesión mediante tradición (traditio) y luego la perdió sin voluntad de su parte, basada en la ficción de la usucapión cumplida (Gai. 4, 36). Ella quedó recogida después en Dig. 6, 2 (De Publiciana in rem actione). Véase Cuesta Sanz, La acción publiciana, cit., 29-124. Coing, H., Derecho privado europeo, cit., I, 379, explica que en el derecho común la acción publiciana siguió siendo utilizada. De hecho, la práctica alemana la prefería a la reivindicatoria por ser más fácil de demostrar sus requisitos. Su pervivencia a partir de la codificación ya ha sido referida en la nota 7.

25 Con lo que adquiere sentido la partición entre acciones reales y personales que hace Gai. 4, 5.

26 CoIng, H., Derecho privado europeo, cit., I, 375.

27 Rogel Vide, C., Alcolado Chico, M. y de Lamo Merlini, O., "Vindicar y reivindicar", Foro, nueva época, n. 1, 2005, 68, y Sciumè, A., s.v. "Rivendicazione (dir. intermedio)", cit., 48. 
persona a cuyo nombre posee (Cod. $3,19,2)^{28}$, excusa que mereció especial atención de parte del derecho longobardo ${ }^{29}$. En el derecho castellano, la regla también quedó recogida (p. ej., Part. 3, 2, 29).

La protección jurídica de la propiedad se configuró en los derechos nacionales del siglo XIX siguiendo de cerca el modelo romano y las elaboraciones habidas durante el derecho común ${ }^{30}$. Sin embargo, el paradigmático Code civil francés (1804) no se ocupó de la reivindicación más que de manera tangencial ${ }^{31}$. De ella tratan unas pocas normas: (i) el artículo 526 califica como inmueble la acción reivindicatoria que persigue esa clase de bienes; (ii) el artículo 549 señala que el poseedor de mala fe es obligado a restituir los frutos junto con la cosa que se reivindica; (iii) el artículo 1553 permite al comprador suspender el pago del precio si teme verse privado de la cosa por el ejercicio de una acción reivindicatoria; (iv) el artículo 1926 concede al depositante que ha entregado una cosa en depósito a un incapaz solo la acción reivindicatoria, si la cosa subsiste, o bien lo faculta para reclamar el provecho que el depositario recibió por ella; (v) el artículo 2279 (hoy 2276) permite reivindicar una cosa mueble que se ha perdido o ha sido robada dentro de un plazo de tres años. A partir de estas referencias, la doctrina fue construyendo un régimen para la reivindicación que permite al dueño perseguir la cosa de manos de quien la tenga, aunque la operatividad de esta tutela ofensiva de la propiedad queda reservada a los inmuebles y para las cosas muebles que han sido hurtadas o robadas (rigiendo para los demás la regla “meubles n'ont pas de suite" $\left.{ }^{32}\right)^{33}$. Con todo, en la actualidad la reivindicatoria es una acción en declive en Francia, que raramente se ejerce ${ }^{34}$.

Distinto fue el caso del código civil chileno, que reservó una minuciosa regulación para la reivindicación hacia el final del libro in dedicado a los bienes. Para lo que ahora interesa, Bello realizó una curiosa operación al disponer los distintos casos de “contra quién se puede reivindicar" (libro II, título XII, $\S 3$ ), pues uno de los supuestos en que el derecho romano posclásico había permitido la reivindicación contra un poseedor ficticio (el del falso poseedor) fue transformado en una mera acción perso-

28 CoIng, H., Derecho privado europeo, cit., I, 374.

29 Sciumè, A., s.v. "Rivendicazione (dir. intermedio)", cit., 33.

30 Coing, H., Derecho privado europeo, cit., II, 482.

31 Sciumè, A., s.v. "Rivendicazione (dir. intermedio)", cit., 45.

32 La fuente del Code civil francés parece ser Boujon, F., Le droit commun de la France, Paris, Grangé, Cellot, 1770, lib. II, cap. vi, sec. 1-3, t. I, 145, quien conectaba esta regla con aquella otra según la cual "fait de meuble la possession vaut titre", y señalaba que esa era la práctica de la época.

33 Véase, p. ej., Carbonnier, J., Droit civil, iII, 19. a ed., Paris, Puf, 2000, núm. 205 (322-323) y 227 (357-358); Cornu, G., Droit civil. Introduction Les personnes. Les biens, 6. a ed., Paris, Montchrestien, 1993, núm. 1633 (542) y 1641 (546); Larroumet, C, Droit civil, il, 2. a ed., Paris, Economica, 1988, núm. 683 (407-409) y 916 (594-595); Malaurie, P. y AynÈs, L., Les biens, 6. ${ }^{\text {a }}$ ed., Paris, LGDJ, 2015, núm. 460 (155) y núm. 581 (200); Planiol, M. y Ripert, G., Traité pratique de droit civil français, III, 2. ' ed., Paris, LGDJ, 1952, núm. 351 (348) y núm. 367 (363-364); TERRÉ, F. y SimLER, P., Droit civil. Les biens, 9. a ed., Paris, Dalloz, 2014, núm. 520-521 (409-410) y núm. 530 (415-418).

Malaurie, P. y Aynès, L., Les biens, cit., núm. 460, 155. 
nal de resarcimiento de perjuicios (art. 897 c.c.), como ya ocurría en Pothier, mientras que otros dos (aquellos en que el demandado no tiene ya la cosa en su poder), en los que era claro su carácter de acción personal (por recoger respectivamente una condictio pretii y una condictio furtiva), fueron convertidos por equiparación formal en una acción de dominio (art. 898 c.c.) ${ }^{35}$.

La acción indemnizatoria contra el falso poseedor pasó a los demás códigos civiles hispanoamericanos dependientes del chileno o influidos por él ${ }^{36}$. Así pues, con una redacción muy similar a la que Bello dio al describir dicha acción, ella fue recogida por el código civil argentino aprobado en 1869 (art. 2784), aunque no se conservó en el Código Civil y Comercial de la Nación en vigor desde el 1. ' de agosto de $2015^{[37]}$. El código civil uruguayo aprobado un año antes que el proyecto de Vélez Sarsfield conserva una redacción equivalente al artículo 897 c.c., salvo por la reformulación de la parte inicial de la regla para sustituir "mala fe" por "dolosamente" (art. 683). Por su parte, el código civil colombiano (1887) reproduce sin cambios la misma disposición presente en el código chileno (art. 954).

\section{El supuesto de hecho}

El análisis del supuesto de hecho descrito por el artículo 897 c.c. exige ocuparse de la legitimación activa (A) y pasiva (B) de la acción resarcitoria que ahí se concede, y del factor de atribución de responsabilidad con que ella opera (D). Con todo, dicha acción resulta inseparable del deber de información que pesa sobre el mero tenedor para aclarar la situación de la cosa demandada (C).

\section{A. La legitimación activa de la acción del artículo 897 c.c.}

La regla del artículo 897 c.c. no exige como parte de su supuesto de hecho que la demanda provenga del dueño, pues simplemente se presenta para el caso de que el actor sufra perjuicios derivados del comportamiento del demandado. Siendo así, el actor puede ser tanto el dueño (art. 893 c.c.) como el que ha perdido la posesión

35 Barrientos Grandon, J., Las 'condictiones' en el código civil. El pago de lo no debido y otros supuestos de su procedencia, Santiago, Thomson Reuters, 2018, 273-282. Con todo, este autor no estima que el código civil haya acabado recalificando la naturaleza formal de las acciones del artículo 898 c.c., como parece desprenderse de su redacción. De esto hemos tratado en Alcalde Silva, J., "Las 'acciones de dominio' del artículo 898 del código civil”, en Gómez dE LA Torre, M., HernánDEZ, G., Lathrop, F. y TAPIA, M. (eds.), Estudios de derecho civil XIV, Santiago, Thomson Reuters, 2019, 267-300.

36 Para un esquema de cuáles fueron esos códigos, véase GuZMÁn BRITO, A., La codificación civil en Iberoamérica. Siglos XIX y XX, Santiago, Jurídica de Chile, 2000, 607.

37 En el Código Civil y Comercial de la Nación Argentina, el supuesto quedó recogido de la siguiente forma: "El tenedor de la cosa a nombre de un tercero puede liberarse de los efectos de la acción si individualiza al poseedor. Si no lo individualiza, queda alcanzado por los efectos de la acción, pero la sentencia no hace cosa juzgada contra el poseedor" (art. 2255 II). 
regular de la cosa y se hallaba en el caso de poder ganarla por prescripción (art. 894 c.c.), porque que en ambos casos se está reivindicando una cosa que otro sostiene poseer sin tener en verdad esa calidad ${ }^{38}$. El elemento determinante de la regla es el perjuicio sufrido por el actor, de suerte que basta con que exista un interés digno de protección (art. 2315 c.c.). Dado que el bien jurídico protegido con la mentada regla es la frustración de la acción reivindicatoria del demandante merced al engaño del demandado, la acción resarcitoria no procede cuando el rechazo de la demanda proviene de otras razones, como la falta de prueba o la falta de legitimación por parte del actor. Pero sí cabe intentarla cuando se ha acogido la demanda y no se puede proceder a la restitución material del bien en la fase de cumplimiento del fallo, por el hecho de que el demandado no es poseedor y, por consiguiente, no puede hacer entrega de algo que no está en su poder.

\section{B. La legitimación pasiva de la acción del artículo 897 c.c.}

En rigor, la acción reivindicatoria se dirige contra el actual poseedor (arts. 889 y 895 c.c. $)^{39}$. Sin embargo, en la práctica se pueden presentar dudas acerca de la identidad de la persona que está efectivamente poseyendo la cosa cuya reivindicación se quiere demandar ${ }^{40}$. Incluso más, la posesión del demandado como supuesto de procedencia de la demanda reivindicatoria puede ser utilizada estratégicamente por aquel para defenderse de una acción correctamente interpuesta, y corresponde que el derecho arbitre los medios que permitan corregir esa situación ${ }^{41}$. Uno de estos mecanismos

38 Rogel, C., Alcolado, M. T. y de Lamo, O., "Vindicar y reivindicar", cit., 66, recuerdan que ya las Partidas asumían que los requisitos de la reclamación del poseedor eran los mismos que aquellos previstos para el dueño. El código civil chileno trata la acción publiciana como un supuesto más de acción reivindicatoria ("[s]e concede la misma acción..."). Por consiguiente, cuando se habla de "juicio reivindicatorio" puede ser tanto aquel iniciado por una acción reivindicatoria propiamente tal (arts. 889 y 893 c.c.) como por una acción publiciana (art. 894 c.c.).

39 Alcalde Silva, J., "El ejercicio de una actividad comercial en un determinado inmueble es suficiente para dar por establecida la posesión. La reivindicación procede también contra el poseedor material, sin que importe la carencia de cualquier inscripción a su respecto. Los bienes reservados revisten el carácter de propios de la mujer. La renuncia a los gananciales tiene cabida incluso cuando la mujer ha declarado cuál es la composición de la comunidad formada tras la disolución de la sociedad conyugal. Corte Suprema, sentencia de 5 de septiembre de 2017 (rol núm. 11.681-2017; CL, JUR, 5819, 2017)", Revista Chilena de Derecho Privado, n. ${ }^{\circ} 29,2017,314-317$, desarrolla el sentido de la expresión "actual poseedor" del artículo 895 c.c., cuyo antecedente último es romano (Dig. 6, 1, 9). Como fuere, el problema no proviene de que la tradición de los inmuebles se deba practicar mediante una inscripción conservatoria (art. 686 c.c.), cuya finalidad es conseguir el anhelo de que inscripción, posesión y propiedad sean términos idénticos (Mensaje del Código Civil, § 22), sino de que la posesión de esa clase de bienes se haya desmaterializado al entenderse que ella existe mientras esté vigente tal inscripción (arts. 696, 724, 728, 924 y 2505 c.c.). En rigor, eso deja sin aplicación la reivindicación como mecanismo para recuperar una cosa propia que otro ocupa con pretensión dominical (art. 904 c.c.), como históricamente entendió la jurisprudencia (véase la nota 5).

40 Peñailillo, D., Los bienes. La propiedad y otros derechos reales, cit., 1456-1457.

41 Atria Lemaitre, F., "El sistema de acciones reales, parte especial: acción reivindicatoria, publiciana y del art. 915)", Ius et Praxis, vol. 23, n. ${ }^{\circ}$ 2, 2017, 169. 
es la condena que se impone a todo aquel que se da por poseedor de la cosa que se reivindica a sabiendas, para frustrar la pretensión del dueño (art. 897 c.c.).

El artículo 897 c.c. se limita a señalar que la legitimación pasiva de la acción resarcitoria ahí concedida corresponde a todo aquel que se da por poseedor de la cosa sin serlo y está de mala fe. Siendo así, el único requisito para que ella prospere es que se trate del demandado del juicio reivindicatorio que el actor ha proseguido inútilmente debido al engaño producido. De esto se sigue que resulta indiferente que ese demandado sea el mero tenedor que no aclara su calidad o cualquier tercero que, sin tener siquiera la tenencia de la cosa ni el ánimo de señor y dueño, pretende ser poseedor dentro del juicio ${ }^{42}$. Por cierto, la regla alcanza igualmente al precarista, vale decir, al que detenta la cosa sin contrato alguno, por ignorancia o mera tolerancia del dueño (art. 2195 II c.c.), si incurre en la conducta descrita en ella ${ }^{43}$.

Por consiguiente, el criterio para determinar la legitimación pasiva de la acción de resarcimiento consiste en que el demandado en el juicio reivindicatorio no haya sido el actual poseedor de la cosa que se le reclama y, de mala fe, se dé por tal. El problema se produce por la disociación entre realidad jurídica y realidad práctica que produjo la decisión de la Comisión Revisora del Proyecto de Código Civil de vincular la posesión de los bienes raíces a la existencia de la respectiva inscripción conservatoria (arts. 686, 696, 702, 724, 728, 729, 924 y 2505 c.c.) y que acaba por incidir en la calidad de "actual poseedor" (art. 895 c.c. $)^{44}$.

Las reglas sobre las que se sustenta la "teoría de la posesión inscrita" fueron introducidas en el Proyecto Inédito, vale decir, durante el primer examen al que fue sometido el Proyecto de 1853 por parte de la comisión conformada por el gobierno y donde tuvieron participación jueces, profesores universitarios y todos quienes habían recibido el encargo de preparar alguno de los códigos previstos dentro del plan general de codificación puesto en marcha por el presidente Manuel Montt ${ }^{45}$. Así ocurrió con los actuales artículos 696 (art. 826 i), 724 (art. 867 a), 728 (art. 873 a), 729

42 Vodanovic Haklika, A., Tratado de los derechos reales, 6. ed., Santiago, Jurídica de Chile, 2011, II, núm. 1220, 284.

43 Esto se debe a que los supuestos de detentación que el código civil admite son solo dos: posesión o mera tenencia (véase la nota 44). Véase, p. ej., Alcalde Silva, J., "Los supuestos de tenencia reconocidos por el derecho. El concepto de título de mera tenencia o no traslaticio de dominio. La sociedad conyugal como título de tenencia suficiente para enervar una acción de precario ejercida por un tercero. La oponibilidad de la sociedad conyugal a terceros por parte de la mujer. El precario entre cónyuges. La legitimación activa de la acción de precario, especialmente cuando es ejercida por un usufructuario. La tutela del usufructuario. Corte Suprema, sentencia de 4 de mayo de 2015 (rol núm. 31.925-2014)", Revista Chilena de Derecho Privado, n. ${ }^{\circ} 26,2016,285-310$, y SELMAN NAнum, A., "Algunas consideraciones sobre el precario y la naturaleza jurídica del precarista”, Ius et Praxis, vol. 24, n. ${ }^{\circ}$ 2, 2018, 341-392.

44 El Mensaje del Código Civil lo explica así: "La inscripción es la que da la posesión real efectiva; y mientras ella no se ha cancelado, el que no ha inscrito su título, no posee: es un mero tenedor" (\$21).

45 Véase Alcalde Silva, J., "Notas para una relectura del sistema de propiedad raíz en el derecho chileno", en Domínguez Hidalgo, C. (ed.), Estudios sobre propiedad y posesión. Perspectiva chilena y latinoamericana, Santiago, Thomson Reuters, 2019, 33-64. 
(art. 874), 924 (art. 1076) y 2505 (art. 2687 b) del código aprobado en $1855^{[46]}$. Por su parte, el artículo 686 c.c. provenía del Proyecto de 1853, pero con una redacción diversa: su artículo 826 establecía un modo opcional de hacer la tradición simbólica para los bienes raíces distinto del ya previsto en el artículo anterior $(825)^{47}$, el cual consistía en registrar "la escritura pública de enajenación en la competente oficina del Conservador de Bienes Raíces y firmando el Conservador la partida, junto con ambas partes o sus apoderados" (inc. $1^{\circ}{ }^{\circ}$ ). Ella impedía una nueva tradición real (art. 823) o simbólica (art. 825) en el futuro, puesto que enseguida se agregaba que, "[t]ransferido de este modo el dominio, no podrá pasar a tercero sino de la misma manera" (inc. $2^{\circ}$ ). La fuente de esta regla es el $\S 431$ ABGB (1811), aunque Bello no lo dejó dicho ${ }^{48}$. Solo hizo presente que este medio de efectuar la tradición de los inmuebles le parecía preferible al existente en el derecho romano (Cod. 8, 53, 1) y castellano (Part. 3, 30, 8), y partía del supuesto de que habría en cada departamento un Registro que se podía agregar al de las hipotecas implementado tras la Real Pragmática del 31 de enero de 1768 y regulado por entonces en el Reglamento del 20 de mayo de 1848. Concluía señalando que esta era una gran innovación del proyecto que proponía al gobierno para su estudio: "Se ha querido preparar por este medio una institución que se halla establecida hoy día con los mejores efectos en varios estados europeos" 49 .

La inspiración inmediata de este cambio radical de criterio respecto de la transferencia de propiedad sobre los inmuebles parece haber estado en las consecuencias extraídas de la adopción de un sistema de inscripción constitutiva como el previsto en el citado $\$ 431 \mathrm{ABGB}^{50}$ y en la lectura del Proyecto de Código Civil español de 1851, el cual se indica como fuente del artículo 2505 c.c. ${ }^{51}$. Esta regla, según la cual no cabe la prescripción adquisitiva contra un título inscrito, es la única de las nor-

46 Aunque el inciso $3 .^{\circ}$ del artículo 702 c.c. proviene del artículo 835 II del Proyecto de 1853 , su inciso 4. ${ }^{\circ}$ solo aparece en la redacción definitiva que figura ya en el artículo 834 del Proyecto Inédito. Cfr. Bello, A., Código civil de República de Chile, cit., 476-477.

47 El artículo 825 del Proyecto de 1853 era sustancialmente coincidente con el artículo 684 c.c., pero con la diferencia de que se aplicaba por igual a los bienes muebles e inmuebles. Por su parte, en el artículo 823 de dicho Proyecto se trataba la tradición real, también aplicable a ambas clases de bienes. Respecto de los inmuebles, ella se hacía de la siguiente manera: "entrando en ellas el que las recibe, a presencia del que las entrega; manifestándose en el uno la voluntad de trasferir el dominio, i en el otro la de adquirirlo".

48 Véase, p. ej., Bravo Lira, B., "En busca de los orígenes del Registro Conservatorio en Chile. Bello y el abGB”, en Sepúlveda Larroucau, M. A., Teoría general del derecho registral inmobiliario, Santiago, Metropolitana, 2014, 19-24, y ZÁrate GonZÁlez, S., Tratado de derecho inmobiliario registral, Santiago, Metropolitana, 2019, 155-212.

49 Bello López, A., Obras completas de don Andrés Bello, XII, Santiago, Imprenta de G. Ramírez, 1888, 186-187.

50 Mery Berisso, R., "El código civil de la República de Chile y los tribunales de justicia”, Anales de la Universidad de Chile, $\mathrm{n} .{ }^{\circ} 103,1946,104$.

51 Amunátegui, Código civil de Chile, cit., 633; Bello, Código civil de República de Chile, cit., 1026, y Barrientos, El código civil, cit., 1171. 
mas que conforman la "teoría de la posesión inscrita" donde Bello dejó consignada una fuente, remitiendo a las Concordancias, motivos y comentarios al Código Civil español (1852) escritas por Florencio García Goyena (1783-1855) ${ }^{52}$. De hecho, la redacción del artículo 1946 II del Proyecto de Código Civil español de 1851 era casi idéntica a aquella que quedó recogida en el Proyecto Inédito y de donde pasó al código civil aprobado en 1855 por el Congreso Nacional ${ }^{53}$. Según García Goyena, la fuente de dicha regla era el $§ 511$ de la sección Ix del título Ix del código prusiano de 1794 (el Allgemeines Landrecht für die Preussischen Staaten) ${ }^{54}$, y constituía "un homenaje tributado al nuevo sistema hipotecario; una consecuencia rigorosa de los artículos 1826 y 1858 [del Proyecto de 1851]"55. La primera de esas normas se refería a la tradición de bienes inmuebles y era equivalente al artículo 686 c.c.; mientras que la segunda disponía que ninguno de los títulos que se debía inscribir producía efectos respecto de terceros hasta que se hubiese practicado la inscripción respectiva, con un efecto similar al que subyace en el artículo 696 c.c. ${ }^{56}$.

52 Al margen del artículo 2687 b del Proyecto Inédito, Bello hizo la siguiente anotación: “Goy., Concordancia, 1946". Un mayor desarrollo sobre las fuentes del sistema registral chileno puede verse en Sepúlveda Larroucau, M. A., Teoría general del derecho registral inmobiliario, cit., 157-176, y ZÁrate, Tratado de derecho inmobiliario registral, cit., 159-189, 202-210 y 275-278.

53 Curiosamente, Lira Urquieta, P., "García Goyena y el código civil chileno”, en El código civil chileno y su época, Santiago, Jurídica de Chile, 1956, 85, señala que "falta por entero en García Goyena la institución de la posesión inscrita”, mientras que LAsso GAITE, F., Crónica de la codificación española, IV, Madrid, Comisión General de Codificación, 1970, 294, califica el libro II del código civil chileno como de factura "más próximo al Code". Véase la nota precedente.

54 PrALR I 9 § 511: "Los derechos sobre cosas inmuebles que se encuentran inscritos en el Registro de Hipotecas no pueden extinguirse por la mera falta de uso, ni puede adquirirse un derecho contrario por medio de la prescripción por posesión" ("Rechte auf unbewegliche Sachen, die im Hypothekenbuche eingetragen sind, können weder durch den bloßen Nichtgebrauch erlöschen, noch kann ein denenselben entgegenstehendes Recht mittelst der Verjährung durch Besitz erworben werden"). Agradezco al Dr. Andrés Schlack Muñoz por la traducción desde el alemán.

55 García Goyena, F., Concordancia, motivos y cometarios del código civil español, reimp. de la ed. de Madrid de 1852, Zaragoza, Cometa, 1974, 1002.

56 La relación entre inscripción y tradición ha suscitado diversas opiniones en la doctrina española con posterioridad la Ley Hipotecaria (la primera de ellas del 8 de febrero de 1861; la actualmente en vigor data del 8 de febrero de 1946) y el código civil (1889). Se admite como principio que la inscripción no ha sustituido a la tradición. La razón es que en el Registro de la Propiedad se inscriben los cambios jurídicos operados de acuerdo al derecho común (arts. 605 c.c. y 1 de la Ley Hipotecaria), por lo que es necesario que haya habido tradición para que exista transferencia de dominio (art. 609 c.c.). El artículo 1462 c.c. señala que la cosa vendida se entiende entregada cuando se pone en poder y posesión del comprador; pero agrega que cuando la venta se hace mediante escritura pública, el otorgamiento de esta equivale a la entrega, si de la misma escritura no resultare o se dedujere claramente lo contrario. Esta escritura es requerida asimismo por la Ley Hipotecaria para practicar la inscripción (arts. 2 y 3). De esto se sigue que en la mayoría de los casos no hay problema, pues existe coincidencia entre los efectos de la tradición y la subsecuente inscripción: si el transferente no es dueño, la escritura pública no puede tener eficacia dominical. La cuestión se suscita respecto de terceros, puesto que el artículo 606 c.c. señala que los títulos de dominio, o de otros derechos reales sobre bienes inmuebles, que no están debidamente inscritos o anotados en el Registro de la Propiedad, no perjudican a terceros. Así pues, respecto del tercero protegido por el artículo 34 de la Ley Hipotecaria y que procede por analogía en la forma establecida en el artículo 36 de la misma ley, la fe pública registral subsana este presupuesto de adquisición, de manera que la inscripción 


\section{El deber de información que pesa sobre el mero tenedor}

Por cierto, el artículo 897 c.c. es en parte una consecuencia del deber establecido en el artículo precedente (que recoge la figura conocida como nominatio auctoris), cuyo origen también se encuentra en el primer manuscrito del título sobre la reivindicación (art. 12) y en el Proyecto de 1853 (art. 1042), según la cual "[e]l mero tenedor de la cosa que se reivindica es obligado a declarar el nombre y residencia de la persona a cuyo nombre la tiene". Eso significa que, sea que previamente se prepare la demanda citándolo para que indique quién es el actual poseedor (art. 282 c.p.c.), sea que ella se dirija directamente contra él y deba oponer una excepción dilatoria para corregir el procedimiento (art. 303, núm. 6 c.p.c.), sobre el mero tenedor siempre pesa un deber de información hacia el reivindicador basado en la dependencia de su titularidad (art. 714 c.c.) ${ }^{57}$. De esta manera, el mero tenedor debe poner en conocimiento del actor y del tribunal que no es el verdadero poseedor de la cosa desde que llega a descubrir esta circunstancia, indicando quién lo es y a qué título detenta la cosa, para que el juicio se pueda dirigir contra quien corresponda ${ }^{58}$. Como fuere, el deber de comunicación puede ser generalizado en sede procesal por exigencia de la buena fe a todo demandado que no se encuentre en la situación posesoria que el demandante le atribuye, para evitar la prosecución de un juicio inútil.

Cuestión aparte será el modo en que ese incidente se tramite, por las particularidades del proceso civil chileno. Pero no parece admisible que la acción reivindicatoria pueda seguir adelante y se transforme en una de daños y perjuicios (arts. 261 y 312 c.p.c.), como se ha sostenido en otros ordenamientos, puesto que esa sustitución de acciones no resulta procedente ${ }^{59}$. Con la Ley 20.886 , sobre tramitación electrónica, que concede al juez facultades para prevenir, corregir y sancionar, incluso de oficio, las conductas de los litigantes donde se observe que existe mala fe (art. $2^{\circ}$, letra d), cabe concluir que podría existir fundamento para una terminación

sí suple la tradición. Véase Rodríguez-Rosado, B., "Protección de los terceros adquirentes y de los acreedores en los diversos sistemas transmisivos: un intento de valoración", Revista Crítica de Derecho Inmobiliario, n. ${ }^{\circ} 733,2012,2645-2671$, e ID., "La equivalencia de la escritura a la entrega y el valor de la tradición instrumental”, en DíEz-PicAzo, L. (coord.), Estudios jurídicos en homenaje al profesor José María Miquel, Cizur Menor, Aranzadi, Thomson Reuters, 2014, II, 2813-2831.

57 De hecho, la redacción del actual artículo 896 c.c. era diversa en el primer manuscrito del "Título 9. De la reivindicación". Su artículo 12 decía: "Dirigida [la acción reivindicatoria] contra el mero tenedor, será éste obligado a declarar el nombre i residencia de la persona a cuyo nombre lo tiene". En el artículo 1042 del Proyecto de 1853, la regla tiene ya su redacción definitiva. Cfr. BARRIENTOS, J., El código civil, cit., 1039.

58 Claro Solar, L., Explicaciones de derecho civil chileno y comparado, Ix, Santiago, Nascimento, 1934, núm. 1748, 408.

59 KIPER, C., Juicio de acciones reales, Buenos Aires, Hammurabi, 2010, 120, postulaba esta posibilidad a partir del artículo 2784 c.c. argentino de 1869. KIPER, C., Manual de derechos reales, 2. ${ }^{\text {a }}$ ed., Córdoba, Rubinzal-Culzoni, 2018, 663, y SAUCEDo, R., “Acciones reales”, en GuRfinkel DE Wendy, L., Derechos reales, Buenos Aires, Abeledo Perrot, 2016, I, 1340, concluyen de igual forma para el Código Civil y Comercial de la Nación hoy en vigor. 
extraordinaria del juicio, sobre la base de los principios de oportunidad y economía procesal, cuando llega a ser evidente que el demandado se irroga maliciosamente una situación legitimante que no tiene. La forma de intentarla será a través de un incidente innominado (art. 82 c.p.c.), que debe ser promovido por el demandado tan pronto se haya cerciorado de que otro es el poseedor actual de la cosa que se le reclama (art. 85 c.p.c.).

\section{La mala fe como requisito indispensable para la procedencia de la acción}

La responsabilidad por los perjuicios causados al reivindicador proviene parcialmente del deber recién descrito y de la concurrencia de un criterio de atribución subjetivo único, como es la mala fe. No hay exacta coincidencia entre el incumplimiento del deber y el supuesto de responsabilidad del artículo 897 c.c., porque el legitimado pasivo de la pretensión resarcitoria no es solo el mero tenedor que se da por poseedor de la cosa sin serlo, sino cualquiera que tenga ese comportamiento y esté de mala fe. En otras palabras, la efectiva detentación material de la cosa es indiferente para atribuir el deber de indemnizar: este proviene del comportamiento lesivo que significa el engaño dirigido contra el reivindicador de aparentar que se es poseedor con el propósito de perjudicarlo (art. 44 vi c.c.).

Ha quedado dicho que el Proyecto de 1853 contenía dos supuestos diferentes respecto de aquel que se daba como poseedor de la cosa sin serlo dentro de un juicio reivindicatorio. En rigor, el caso de quien comete ese error de buena fe no queda cubierto por el artículo 897 c.c., y la solución habrá que buscarla en la disciplina sobre las costas del código de procedimiento civil (libro I, título xIV). La regla que ahí se prevé es que esa condena recae sobre la parte que ha sido vencida totalmente en el juicio, salvo que el tribunal decida eximirla por haber tenido motivos plausibles para litigar (art. 144 c.p.c.). Bajo esta regla, aquel que se da por poseedor de una cosa sin serlo y está de buena fe no puede ser condenado en costas, pues no se trata de la parte vencida en el juicio. La reivindicación será rechazada por la carencia de legitimación pasiva del demandado y, por consiguiente, la calidad de parte vencida corresponderá en realidad al actor. De esto se sigue que el artículo 897 c.c. solo comprende el caso de quien sostenga ser poseedor de la cosa con la conciencia de que no lo es, para así conseguir el rechazo de la demanda intentada por el dueño, haya o no aquiescencia del verdadero poseedor en ese engaño ${ }^{60}$. La mala fe comporta, entonces, el factor de atribución exigido por la regla, y ella viene a ser sinónimo de actuar a sabiendas de que no se es poseedor de la cosa demandada, con el propósito de que el actor no pueda recuperarla y resulte perjudicado en su titularidad ${ }^{61}$. Por eso es que no la hay

60 KIPER, C., Juicio de acciones reales, cit., 121, consideraba que, si la situación del demandado era inexcusable, quedaba igualmente incurso en la responsabilidad que preveía el artículo 2784 del antiguo código civil argentino.

61 Alferillo, P., "La 'mala fe"”, Universitas, n. ${ }^{\circ}$ 122, 2011, 461. 
(i) cuando existe un error excusable que justifique la aserción posesoria del demandado $^{62}$, (ii) cuando este no litiga con la intención de perjudicar (animus nocendi) al reivindicador, sea que este último tenga o no medios para darse cuenta de la verdad de las cosas (p. ej., el heredero que cree sinceramente que su causante era el poseedor de la cosa que solo tenía como mero tenedor) ${ }^{63}$, o (iii) cuando el actor hubiere podido con diligencia al menos mediana darse cuenta del engaño y enterarse de quién era realmente el poseedor de la cosa que reivindica ${ }^{64}$.

Para que se configure el supuesto del artículo 897 c.c. basta que exista un engaño del falso poseedor comprobado objetivamente. Esto significa que es suficiente con que se verifique una falta de verdad en lo que este dice o hace en el juicio reivindicatorio, para causar un perjuicio al actor consistente en el rechazo de su demanda ${ }^{65}$. Dicha actitud procesal denota por sí misma dolo o mala fe, y consiste en la falsa aserción del demandado sobre su calidad hacia la cosa que se pretende, vale decir, que sepa que no es poseedor de ella y, pese a ello, asuma dicha posición, sin desvirtuar la condición que le atribuye el reivindicador ${ }^{66}$. Este comportamiento se puede dar tanto antes como después de la presentación de la demanda ${ }^{67}$, puesto que el elemento relevante para configurar la imputación es que el actor asuma que una determinada persona es el poseedor movido por lo que este dice o hace faltando a la verdad ${ }^{68}$. De esto se sigue que, concurriendo esa falsa aserción, se acredita inmediatamente la imputación subjetiva, sin que sea necesario indagar en los propósitos perseguidos por el demandado que prosigue el juicio a sabiendas de que no es poseedor. La única exigencia que se desprende de la formulación de la regla es que el engaño provenga (y se pruebe que así ha sido) de la propia parte, y no de su mandatario judicial ${ }^{69}$. En este

62 KIPER, C., Juicio de acciones reales, cit., 121.

63 Claro, L., Explicaciones de derecho civil chileno y comparado, cit., núm. 1748, 409.

64 Ibíd., 409.

65 Escriche y Martín, J., Diccionario razonado de legislación y jurisprudencia, nueva ed., Paris, Librería de Rosa Bouret y Cie., 1852, 619, y Muñoz Machado, S. (dir.), Diccionario del español jurídico, Barcelona, Espasa, 2016, 748.

66 Vélez Sarsfield señalaba esta idea como glosa al artículo 2784 del código civil argentino de 1869 : "Si alguno se dice poseedor de una cosa que no posee, y que yo quiero reivindicar, es responsable del perjuicio que pueda resultarme de su falsa aserción a no ser que su falta de posesión me fuese conocida".

67 KIPER, C., Juicio de acciones reales, cit., 121.

68 Por ejemplo, el falso poseedor podría desplegar sus engaños antes de la presentación de la demanda, haciendo creer al futuro reivindicador que él es el actual poseedor de la cosa. Cuando la demanda se presenta y el juicio comienza en su contra, opta por una actitud pasiva y deja que las cosas sigan su curso sin preocuparse de intervenir. Finalmente, la acción es rechazada porque no se logra acreditar que el demandado es poseedor. Como el reivindicador ha sufrido un perjuicio y este proviene del engaño inicial del que fue víctima por parte del falso poseedor, la acción resarcitoria del artículo 897 c.c. procede igualmente.

69 Alessandri Rodríguez, A., De la responsabilidad extra-contractual en el derecho civil chileno, 2. ${ }^{\text {a }}$ ed., Santiago, Ediar-Cono Sur, 1983, núm. 217, 312-314; BARros Bourie, E., Tratado de responsabilidad extracontractual, Santiago, Jurídica de Chile, 2006, núm. 782, 986; Corral Talciani, H., 
último caso, la responsabilidad habrá que perseguirla conforme a las reglas generales, sea de manera exclusiva en sede extracontractual (art. 2314 c.c.), sea incluyendo una condena por infracción a la ética profesional (art. 4. ${ }^{\circ}$ DL 3621/1981), a menos que él y su mandante estén concertados para consumar el engaño (art. 2316 c.c.).

Quien sí puede quedar incurso en la condena basada en el artículo 897 c.c. es el verdadero poseedor, si tiene algún grado de participación en la autoría del engaño o coopera en su realización por actos anteriores o simultáneos (art. 2316 c.c.). Pero además cabe un supuesto diverso, donde el poseedor queda obligado de manera individual por el provecho obtenido del dolo desplegado por el demandado (art. 2316 II c.c. $)^{70}$. En principio, puede que la conducta dolosa desplegada por el demandado en el juicio reivindicatorio no esté enderezada a beneficiar al verdadero poseedor, de manera que sea solo una suerte de acto de emulación hacia el demandante sin correspondencia dominical. En ese caso, el poseedor igualmente resulta beneficiado con la dilación que ha supuesto la actitud del demandado de hacer continuar el juicio en vano, sin que sea posible dictar una condena contra él, puesto que entretanto se ha cumplido el plazo de prescripción a su favor y ha ganado el dominio de la cosa. Esta adquisición es un provecho que puede cuantificarse conforme a las reglas del enriquecimiento injustificado, aunque propiamente no revista ese carácter ${ }^{71}$, y ser reclamado directamente al poseedor, con independencia de la acción resarcitoria contra el demandado de mala $\mathrm{fe}^{72}$. Cuestión distinta es si ese provecho debe ser descontado

Lecciones de responsabilidad civil extracontractual, 2. ${ }^{\text {a }}$ ed., Santiago, Thomson Reuters, 2013, 234;

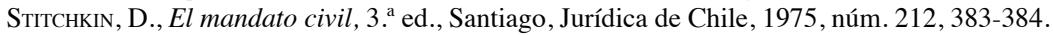

70 El supuesto de hecho de esta acción requiere que el demandado sea inocente de la acción u omisión dolosa que ha afectado al demandante, puesto que su obligación nace por la ganancia que ha obtenido y, por tanto, se extiende "hasta concurrencia de lo que valga el provecho".

71 En rigor, no se trata de un caso de enriquecimiento injustificado porque el poseedor se convierte en dueño en virtud del transcurso del tiempo y de su propia posesión (arts. 2492 y 2498 c.c.), sin que la conducta del falso poseedor sea determinante para que opere a su favor un modo de adquirir el dominio previsto por la ley.

72 Ha existido alguna discusión doctrinal respecto de la naturaleza restitutoria o indemnizatoria de la acción de provecho del dolo ajeno del artículo 2316 II c.c., de la que trata también el artículo 1458 II c.c. a propósito del dolo que incide en la celebración de un contrato. BARros, E., Tratado de responsabilidad extracontractual, cit., núm. 718, p. 932; GARcía MeKis, B., "La naturaleza jurídica de la acción por provecho del dolo ajeno a la luz del denominado 'Caso Inverlink", Actualidad Jurídica, n. ${ }^{\circ} 33,2016,353$; Pino Emhart, A., "La restitución de ganancias ilícitas y la acción de provecho del dolo ajeno", Ius et Praxis, vol. 22, n. 1, 2016, 256-257; Pino Emhart, A., "Los supuestos de restitución de ganancias ilícitas en el derecho privado chileno", Revista Chilena de Derecho, vol. 46, n. ${ }^{\circ}$ 2, 2019, 387, y Pizarro Wilson, C., "La acción de restitución por provecho del dolo ajeno", en Pizarro Wilson, C. (ed.), Estudios de derecho civil IV, Santiago, Legal Publishing, 2009, 682, se inclinan por asignarle el primer carácter. Por el contrario, Alessandri, A., De la responsabilidad extra-contractual en el derecho civil chileno, cit., núm. 398, 482; B ARRIENTOs, J., El código civil, , cit., 1068, Corral, H., Lecciones de responsabilidad civil extracontractual, cit., 366-367; Domínguez, R., "Sobre el artículo 2316 inciso segundo del código civil y la acción contra el que recibe provecho del dolo ajeno", Revista de Derecho de la Universidad de Concepción, n. ${ }^{\circ}$ 225-226, 2009, 221-222, y TAPIA SuÁREz, O., De la responsabilidad civil en general y de la responsabilidad delictual entre contratantes, 2. ${ }^{\text {a }}$ ed., Santiago, LexisNexis, 2006, 291-293, a la vista del tenor literal de las reglas 
del daño resarcible, sobre lo que habrá que volver más adelante ${ }^{73}$. Si la prescripción no se ha consumado respecto del poseedor, de suerte que el dueño puede todavía dirigir la acción reivindicatoria contra él, no parece existir ningún provecho a su respecto y, aunque lo hubiese, es dable concluir que la acción reivindicatoria tiene preeminencia y absorbe (a través de las prestaciones mutuas) cualquier otra presentación de enriquecimiento que pudiese existir. Fuera de este caso, no existe ninguna regla que imponga la subsidiaridad de la acción de restitución de provechos, aunque ese carácter se ha sostenido como una característica general por algunos autores ${ }^{74}$, por lo que la limitación vendrá más bien por la restricción de una doble cobertura de la misma partida (la cosa perdida para el reivindicador valorada en cuanto perjuicio y en cuanto provecho $)^{75}$. De igual forma, resulta interesante preguntarse si la acción por el provecho del dolo ajeno contra el poseedor puede ser intentada por el reivindicador que tenía conocimiento de que el demandado no revestía esa calidad y prosiguió igualmente el juicio a su respecto. De hecho, en otros ordenamientos es posible encontrar reglas donde la culpa de la víctima es uno de los elementos que se toma en consideración para moderar la cuantía de restitución que el juez debe conceder al afectado, como ocurre en el artículo 1302-2 II del reformado Code civil francés ${ }^{76}$.

Dado que la mala fe es el factor de atribución de responsabilidad exigido por la regla del artículo 897 c.c., su prueba incumbe al demandante (art. 1698 c.c.) ${ }^{77}$. De ahí que se haya resuelto, por ejemplo, que el hecho de contestar el demandado la demanda en la que se le pedía la restitución de un predio que había vendido ocho años antes no era argumento para sostener que el demandado participó en el juicio de mala fe, especialmente si se tenía en cuenta que como vendedor era responsable de la evicción y el saneamiento ${ }^{78}$.

Por cierto, el reivindicador no puede reclamar la indemnización que le acuerda el artículo 897 c.c. si tenía conocimiento del falso emplazamiento del demandado,

en cuestión y de su historia legislativa, optan por considerar a la acción como un supuesto reflejo de resarcimiento del daño extracontractual.

73 Véase infra, IV, B.

74 Véase, p. ej., Fueyo LANERI, F., Instituciones de derecho civil moderno, Santiago, Jurídica de Chile, 1990, 471, y Peñailillo Arévalo, D., "Enriquecimiento sin causa. Principio de derecho y fuente de obligaciones", Revista de Derecho de la Universidad de Concepción, n. ${ }^{\circ}$ 200, 1996, 24-27. Por su parte, para Pino, A., "Los supuestos de restitución de ganancias ilícitas en el derecho privado chileno", cit., 391, el régimen de cada acción es el que permite determinar "si es posible o no justificar algún grado de subsidiariedad".

75 La subsidiaridad de la acción de enriquecimiento injustificado ha sido reconocida por los códigos de más reciente elaboración. Así ocurre, por ejemplo, en el reformado Code civil francés (art. 1303-3) y en el Código Civil y Comercial de la Nación Argentina (art. 1795).

76 Con mayor desarrollo, SAN MARTín NeIRA, L., La culpa de la víctima en la responsabilidad civil, Santiago, DER Ediciones, 2018, 229-233, explica los criterios que se han tenido en cuenta en el derecho comparado para reducir la condena a partir de la culpa de la víctima.

77 Claro, L., Explicaciones de derecho civil chileno y comparado, cit., núm. 1748, 409.

78 Sentencia Corte de Apelaciones de Santiago 10 de julio de 1865, Gaceta de los Tribunales, 1865, núm. 1337, 557-558. 
sin importar el momento en que se dé cuenta de este hecho, puesto que eso significaría permitirle instrumentalizar el proceso para ver si consigue tener la suerte de que el tribunal, pese a no existir respaldo para su pretensión, la acoja ${ }^{79}$. Cuando eso ocurre, hay que concluir que la mitigación del resarcimiento impuesto por la exposición imprudente al daño de quien lo sufre (art. 2330 c.c.) llega hasta eliminarlo completamente, ya que la parte afectada era consciente de la verdad del contexto en el que supuestamente se le habrían producido los perjuicios, y podía haber evitado continuar con la prosecución del juicio, dirigiendo su acción contra quien correspondía ${ }^{80}$. Desde el punto de vista procesal, el aviso de que el demandado no es el actual poseedor habrá de hacerse mediante un incidente innominado fundado en la pérdida de la situación legitimante de aquel (art. 82 c.p.c.), que debe ser promovido tan pronto llegue ese hecho a conocimiento del demandante (art. 85 c.p.c.) ${ }^{81}$, o bien como uno de desistimiento de la demanda (art. 148 c.p.c.), puesto que el efecto extintivo de las acciones previsto en el artículo 150 c.p.c. solo opera respecto de los contornos de la propia controversia sometida al tribunal ${ }^{82}$, y el verdadero poseedor no ha sido parte del juicio reivindicatorio (arts. 24 y 177 c.p.c.).

\section{Las consecuencias jurídicas}

La consecuencia que el artículo 897 c.c. atribuye al hecho de que alguien, de mala fe, se dé por poseedor de una cosa sin serlo es convertirlo en responsable de "todo perjuicio que de este engaño haya resultado al actor". La disciplina de esta acción se reconduce así a las reglas sobre responsabilidad civil extracontractual (1), donde tiene crucial importancia determinar cuál ha sido el daño sufrido por el demandante (2) y el momento desde el cual se cuenta la prescripción de la acción (3).

\section{A. La naturaleza indemnizatoria de la acción del artículo 897 c.c.}

La acción descrita en el artículo 897 c.c. es de carácter personal, pues su objetivo es el resarcimiento de los perjuicios sufridos por el demandante como consecuencia de la frustración de su pretensión reivindicatoria ${ }^{83}$. Así pues, y a diferencia de otros supuestos donde el código reenvía a la acción de dominio (arts. 898, 900 y 915 c.c.) ${ }^{84}$,

79 KIPER, C., Juicio de acciones reales, cit.,122.

80 Romero Seguel, A., Curso de derecho procesal civil, i, 3. a ed., Santiago, Thomson Reuters, 2017, 114-116, incluye la buena fe como uno de los límites a la legitimación procesal.

81 Véase supra, III, C.

82 Casarino Viterbo, M., Manual de derecho procesal, iII, 6. a ed., Santiago, Jurídica de Chile, 2005 , 177-178.

83 KIPER, C., Juicio de acciones reales, cit.,120.

84 Tanto en el artículo 898 c.c. ("[l] a acción de dominio tendrá también lugar...”) como en el artículo 900 c.c. (“... podrá intentarse la acción de dominio...”) se hace expresa alusión a que la pretensión ahí concedida es la misma acción reivindicatoria. Alguna discusión puede existir respecto del ar- 
en este caso no se mienta una acción donde existe una divergencia entre la forma y el fondo de la pretensión ejercida: aquí se trata de indemnizar los perjuicios sufridos por la mala fe desplegada con ocasión del juicio en que el actor perseguía reivindicar una cosa determinada, sin que exista una subrogación real respecto de esta última. De esto se sigue que ha de haber dos juicios diversos: (i) aquel donde se ejerce la acción reivindicatoria y en el cual el demandando finge, de mala fe, ser poseedor de la cosa sin que eso sea verdad, y (ii) aquel donde se reclama el resarcimiento de los daños seguidos de ese engaño. Esto significa que nada impide que el demandante pueda presentar una nueva demanda contra el verdadero poseedor, dado que no existe cosa juzgada a su respecto (art. 177 c.p.c.) ${ }^{85}$. La indemnización de los perjuicios causados al actor proviene de un hecho nuevo, como es el engaño ocurrido en el primer juicio, y ella es independiente de la suerte que tenga aquel en la recuperación material de la cosa. Esta última solo tendrá influencia para determinar la cuantía del daño indemnizable. Por consiguiente, la mentada acción se rige por la disciplina de la responsabilidad extracontractual, dado que no existe un vínculo anterior entre el reivindicador y el que se da por poseedor de la cosa sin serlo (arts. 2284 y 2314 c.c.), y el tribunal competente para presentar la demanda será el del domicilio del demandado (art. 134 del Código Orgánico de Tribunales de Chile, c.o.t.).

La exigencia de dos juicios diversos proviene de que resulta discutible que sea procesalmente admisible una condena por parte del tribunal diversa de aquella que fue solicitada por el demandante, incluso si en la demanda se había ejercido la misma acción en términos alternativos ${ }^{86}$. En este sentido, no es posible que las dos acciones (la reivindicatoria del artículo 889 c.c. y la resarcitoria del artículo 897 c.c.) se puedan ejercer entre sí como subsidiarias, de manera que el juez condene

tículo 915 c.c., que aparece recién con el Proyecto Inédito (art. 1066), pues en él solo se señala que "[l]as reglas de este título" (el título XII del libro II sobre reivindicación) resultan aplicables respecto del que posee a nombre ajeno una cosa mueble o inmueble y la retiene indebidamente, aunque lo haga careciendo de ánimo de señor, sin que exista una calificación formal de la acción. Pero la verdad es que la remisión a las reglas sobre reivindicación únicamente tiene sentido en la parte no resuelta por la propia norma, vale decir, respecto de aquellos aspectos distintos de la legitimación pasiva de la acción. Esto significa que la disciplina sobre legitimación activa, cosas reivindicables y prestaciones mutuas sí resulta aplicable, con lo cual la acción del artículo 915 c.c. tiene una fisonomía casi idéntica a la acción de dominio.

85 Pichonnaz, P., Les fondements romains du droit privé, Paris, LGDJ, 2008, núm. 1338, 295. Claro, L., Explicaciones de derecho civil chileno y comparado, cit., 1748, 409, se limita a decir que "el juicio de reivindicación [...] es evidentemente sin efecto contra el verdadero poseedor que no ha litigado". Más categórico era Vélez Sarsfield en su glosa al artículo 2784 del código civil argentino de 1869: "En todos los casos, el que se ha presentado al ser citado a juicio como poseedor y engaña al demandante debe ser considerado y condenado como tal, al pago de todos los perjuicios sufridos por el demandante, y si después es conocido el verdadero poseedor, la acción contra éste queda a salvo".

86 La situación era distinta en el antiguo castellano, y eso explica el límite impuesto por los artículos 216 y 318 c.p.c. Véase García Goyena, F. y Aguirre, J., Febrero ó librería de los jueces, abogados y escribanos, Madrid, I. Boix, vi, 1842, núm. 4541, 4-5, y el Mensaje del Código de Procedimiento Civil, § 25. 
al demandando cuando durante la secuela del juicio se ha demostrado que no era poseedor y solo se hizo pasar por tal con el propósito de perjudicar al demandante (art. 17 c.p.c.), puesto que ese comportamiento procesal es un indicio de que el actor no está totalmente seguro de que el demandado tiene la calidad que le atribuye ${ }^{87}$.

\section{B. Los daños indemnizables}

El artículo 2314 c.c. sienta la regla de que todo aquel que ha cometido un delito o un cuasidelito que ha causado un perjuicio a otro es obligado a su reparación, regla desde la cual se ha formulado el principio de reparación integral del daño ${ }^{88}$. De esta manera, y acreditado algún criterio de reproche (culpa o dolo) respecto del responsable, este queda obligado a resarcir todos los perjuicios que causalmente se puedan conectar con su acción u omisión. Para el derecho chileno, Banfi ha ofrecido una relectura del funcionamiento de las reglas de imputación subjetiva y objetiva del daño extracontractual, sosteniendo que la reparación completa de los perjuicios directos (previstos e imprevistos) debería quedar reducida solamente a los supuestos de ilícitos dolosos, de forma similar a lo que sucede en la responsabilidad contractual (art. 1558 c.c.) ${ }^{89}$. Como fuere, y puesto que la regla aquí analizada parte de la base de que el comportamiento del demandado ha sido de mala fe, la cuestión en torno al acotamiento que el factor de imputación subjetiva introduce en la cuantía de la indemnización no resulta relevante, por lo que sus límites se deben buscar en los criterios que componen la imputación objetiva y en las partidas de perjuicios que pueden integrar esa indemnización.

La delimitación de los daños indemnizables según los requisitos exigidos para el resarcimiento y los criterios de imputación objetiva no merece mayor atención, pues no difiere de la formulación general que se hace a propósito de la responsabilidad extracontractual ${ }^{90}$. Mayor interés reviste la tipología de las partidas indemnizables de acuerdo con el artículo 897 c.c. En rigor, los perjuicios a los que se refiere esta regla pueden consistir únicamente en (i) los gastos del juicio inútil que ha hecho

87 En rigor, si así fuese, la prueba habría de recaer también sobre la cuantía de los perjuicios sufridos o, al menos, sobre su existencia, si el demandante se ha reservado la discusión de la especie y el monto de los daños para la fase de ejecución de la sentencia (art. 173 iा c.p.c.).

88 Véase, p. ej., Domínguez Hidalgo, C., "El principio de reparación del daño y su contenido: algunas consecuencias para el derecho chileno", en Departamento de Derecho Privado de la Universidad de Concepción (ed.), Estudios de derecho civil v, Santiago, Legal Publishing, 2010, 671-685, e ID., "El principio de reparación integral del daño: sus contornos", en Domínguez Hidalgo, C. et al. (eds.), Estudios de derecho civil VIII, Santiago, Legal Publishing, 2013, 561-572, y DomínGuEZ Águila, R., "Los límites al principio de reparación integral", Revista Chilena de Derecho Privado, n. ${ }^{\circ} 15,2010,9-28$.

89 BANFi del Río, C., "Por una reparación integral del daño extracontractual limitada a los hechos dolosos o gravemente negligentes", Ius et Praxis, vol. 18, n. ㄹ 2, 2012, 3-32.

90 Véase, p. ej., BARros, E., Tratado de responsabilidad extracontractual, cit., núm. 152-160, 236-247; CORRAl, H., Lecciones de responsabilidad civil extracontractual, cit., 135-141, y DiEZ SCHWERTER, J., El daño extracontractual. Jurisprudencia y doctrina, Santiago, Jurídica de Chile, 2002, 30-64. 
seguir el demandado al reivindicador, en (ii) los frutos dejados de percibir durante el lapso que duró el juicio si la acción se puede todavía intentar contra el verdadero poseedor, o incluso comprender (iii) el valor de la cosa que el demandante ha perdido por la prescripción que este último ha completado durante la secuela del juicio y que no pudo ser oportunamente interrumpida ${ }^{91}$. Todos ellos deben ser probados por el demandante que alega haberlos sufrido como consecuencia del engaño proveniente del falso poseedor durante el juicio reivindicatorio.

Respecto de los gastos, el artículo 897 c.c. opera bajo una clave resarcitoria y, por ende, ellos se valoran conforme al efectivo desembolso que haya efectuado el demandante para proseguir el juicio que ha resultado desfavorable a sus intereses por no ostentar el demandado la calidad de poseedor de la cosa que se reclama. Esto significa que no rige en esta sede la disciplina de las costas prevista en el código de procedimiento civil (libro I, título XIV), la cual supone de parte del tribunal un ejercicio de valoración discrecional de las costas personales y otro concreto en lo que atañe a las costas procesales a partir de los aranceles cobrados por los auxiliares de la administración de justicia y de los demás gastos que ha supuesto la secuela del proceso (art. 140 II c.p.c.) ${ }^{92}$. Aquí, por el contrario, el reivindicador puede cobrar cualquier gasto que le haya supuesto el juicio, sin importar de qué se trate, con tal de que logre probarlo (p. ej., sus propios desplazamientos para entrevistarse con su abogado, los honorarios pagados por un dictamen jurídico solicitado para el juicio reivindicatorio, etc.).

La indemnización de los frutos está condicionada a la posibilidad que tenga el reivindicador de volver a demandar al verdadero poseedor y a las prestaciones mutuas que puede reclamar de este. Si este último estaba de mala fe, es obligado a restituir los frutos naturales y civiles de la cosa, incluyendo los que el dueño hubiera podido percibir con mediana inteligencia y actividad de haber tenido la cosa en su poder (art. 907 i c.c.). Por el contrario, el poseedor de buena fe no debe restituir los frutos percibidos antes de la contestación de la demanda, los cuales hace suyos (art. 907 III c.c.). De esto se sigue que el reivindicador que ejerce nuevamente la acción no puede reclamar a su vez el resarcimiento de los frutos que debe pagar el poseedor de mala fe, dado que este está obligado a hacerse cargo de todos los que haya o pudiese haber producido la cosa; pero sí tiene derecho a hacerlo cuando el poseedor

91 Barros, E., Tratado de responsabilidad extracontractual, cit., núm. 397, 493; Claro, L., Explicaciones de derecho civil chileno y comparado, cit., núm. 1748, 408-409; KIPER, C., Juicio de acciones reales, cit., 121; Mejías, C., Derecho real de domino y acción reivindicatoria. Posesión y acciones posesorias, cit., 55; Vodanovic, A., Tratado de los derechos reales, cit., II, núm. 1220, 284.

92 En rigor, la regulación de las costas personales se debería hacer de manera abstracta de acuerdo con la regla del artículo 139 IV c.p.c., que ordena remitirse al arancel de honorarios del respectivo colegio de abogados, con independencia (aunque computando esa suma) de lo que se hubiese pagado efectivamente al mandatario judicial. Pese a la eliminación de la colegiatura obligatoria merced al artículo 2. ${ }^{\circ}$ DL 3621/1981, dichos aranceles todavía existen. Por ejemplo, el del Colegio Provincial de Abogados de Valparaíso fue aprobado el 14 de junio de 1999 mediante el acuerdo núm. 60-99, y el del Colegio de Abogados de Santiago data del 7 de enero de 1974. 
demandado estaba de buena fe, ya que este solo está obligado a restituir aquellos posteriores al momento en que ha quedado trabada la relación procesal ${ }^{93}$. Esos frutos pueden ser cobrados como perjuicios al falso poseedor.

Por último, el valor de la cosa se avaluará al día en que ella se pierde definitivamente para el dueño, vale decir, desde que deja de estar en su patrimonio porque ya no existe más o porque otro la ha ganado por prescripción adquisitiva (arg. ex art. 900 III c.c.), dado que ese es el momento en que aquel experimenta un daño cierto.

Con todo, el punto más problemático en torno a la determinación del daño indemnizable tiene que ver con la compatibilidad que existe entre la acción indemnizatoria del artículo 897 c.c. y aquella por el provecho del dolo ajeno del artículo 2316 II c.c. ${ }^{94}$. Cuando el dominio de la cosa que se reivindicaba ha sido ganado por el actual poseedor, dicha pérdida comporta una doble condición: es un daño sufrido en el patrimonio del reivindicador y que puede reclamar del demandado que lo distrajo con un juicio inútil, y es también un aumento patrimonial para el poseedor que se ha convertido en dueño. Por cierto, la acción restitutoria se extiende "hasta concurrencia de lo que valga el provecho" (art. 2316 II c.c.), lo que significa que comprende todas las ganancias que se hayan seguido para el poseedor del actuar doloso del demandado original, sin quedar circunscrito al precio de la cosa ganada por prescripción adquisitiva. El único límite es la causalidad de la ganancia obtenida, que debe ser consecuencia de la comisión del ilícito civil de un tercero (el demandado en el original juicio reivindicatorio), pues de lo contrario el demandado quedaría en una posición injustamente ventajosa ${ }^{95}$.

Como fuere, una elemental exigencia de justicia correctiva aconseja evitar que el demandado se vea obligado a efectuar un doble pago al demandante, y eso se logra mediante una imputación de los beneficios que ha obtenido al resarcimiento que puede pretender (compensatio lucri cum damno) ${ }^{96}$. Por lo demás, este es el criterio que establecen los artículos 85 E de la Ley 17.336 y 172 III de la Ley 18.045, que permiten la acumulación de la acción indemnizatoria y de enriquecimiento injustificado respecto de un mismo hecho, pero tomando en cuenta lo que deba pagarse en una y otra para evitar que el demandante obtenga una doble cobertura de la misma contra quien se hizo pasar por tal no resulta posible de acuerdo al artículo 92 c.p.c.

94 Véase supra, II, D.

95 The American Law Institute, Restatement of the Law (Third) Restitution and Unjust Enrichment, Saint Paul, MN, The American Law Institute Publishers, 2011, II, § 51, comentario h).

96 Por ejemplo, esta regla de compensación de imputación o computación de ventajas ha sido recogida por el código civil neerlandés (art. 6:100) y por los Principios Europeos de Responsabilidad Civil (art. 10:103). Véase su fundamentación y requisitos en ElorRIAGA DE BonIs, F., “Compensatio lucri cum damno'. Las eventuales imputaciones a las indemnizaciones de perjuicios”, Revista Anales Derecho $U C$, n. $^{\circ} 7,2011,122-129$. 
partida $^{97}$. Era también lo que proponía el artículo 1045 III del Proyecto de 1853 para la regla hoy recogida en el artículo 898 c.c., donde se disponía que el reivindicador no tenía derecho para que se le restituyese la cosa y el precio, ni para ser indemnizado dos veces por un mismo perjuicio.

\section{La prescripción de la acción}

Ha quedado dicho que la acción de indemnización de perjuicios que el artículo 897 c.c. concede contra el falso poseedor tiene naturaleza extracontractual. Esto significa que ella prescribe a los cuatro años desde perpetrado el acto (art. 2332 c.c.). Sin embargo, el momento inicial del cómputo de este plazo ha sido una cuestión discutida por la doctrina y la jurisprudencia. La opinión mayoritaria y que aquí se comparte se ha decantado por considerar que ese lapso comienza a computarse desde que se ha producido o se ha manifestado el daño, pues resulta injusto que la acción se extinga sin siquiera haberse hecho valer y, sobre todo, porque solo existe un ilícito extracontractual desde que la acción u omisión del agente ha causado un daño a la persona o bienes de otro (arts. 1437,2284 y 2314 c.c.), y no antes ${ }^{98}$.

Esto tiene importancia respecto del supuesto que aquí se ha analizado porque, en razón de las partidas indemnizables previamente revisadas, la producción del daño será diversa en uno y otro caso. Los gastos suponen un daño para el reivindicador desde que se ha desembolsado su valor, los frutos desde que se ha demandado al actual poseedor de buena fe y ese rubro ha sido rechazado por sentencia firme, y la cosa pretendida desde que se ha perdido definitivamente por haberla ganado por prescripción un tercero ${ }^{99}$. En este caso, y dado que la prescripción es una excepción a favor del demandado, la acreditación del día inicial desde el cual ella ha comenzado a correr corresponde al falso poseedor.

\section{Conclusiones}

El propósito perseguido con este trabajo era demostrar que Bello realizó una operación de conversión de la acción tratada en el artículo 897 c.c., que desde el derecho romano posclásico había sido considerado un supuesto de reivindicación ficticia, obrando de manera inversa a como hizo con dos supuestos obligacionales que se transformaron en un caso de acción de dominio merced a la calificación formal del artículo 898 c.c. Por el contrario, en el código chileno esa acción quedó configurada

97 Es también la solución que propone PINO, A., "La restitución de ganancias ilícitas y la acción de provecho del dolo ajeno", cit., 258-264, e ID., "Los supuestos de restitución de ganancias ilícitas en el derecho privado chileno", cit., 392.

98 Véase, p. ej., Barros, E., Tratado de responsabilidad extracontractual, cit., núm. 710-715, 922-929, y Corral, H., Lecciones de responsabilidad civil extracontractual, cit., 399-405.

99 Véase supra, IV, B. 
como un supuesto particular de responsabilidad extracontractual, que procede contra el demandado (sin importar si es mero tenedor, precarista o un tercero cualquiera que no tiene siquiera la tenencia material de la cosa) de un juicio reivindicatorio que se conduce de mala fe y se hace pasar por poseedor. Esto significa que se aplican a su respecto todas las normas propias de este estatuto de responsabilidad, como la fijación del tribunal competente, la extensión del daño resarcible y el plazo de prescripción. El punto que reviste mayor atención es el que dice relación con los perjuicios que puede reclamar el reivindicador afectado, y que van desde los gastos que le ha supuesto el juicio seguido en vano hasta el valor de la cosa que el poseedor ha ganado por prescripción adquisitiva, sin olvidar los frutos que, cuando todavía es posible volver a intentar la acción reivindicatoria, aquel no puede trasladar al actual poseedor. La concreta partida reclamada determinará la existencia de un daño cierto y, por ende, el día inicial para computar el plazo de cuatro años previsto en el artículo 2332 c.c. Fuera de esa acción, es posible el nacimiento paralelo de aquella contemplada en el artículo 2316 II c.c. y que permite reclamar del verdadero poseedor el provecho que le ha significado la actuación dolosa del demandado del primer juicio. Con todo, la compatibilidad de ambas acciones exige tener en cuenta que el demandante no puede resultar beneficiado más allá de lo que le corresponde, vale decir, no puede conseguir una doble cobertura de la misma partida, que en un caso representa un daño causado por un actuar de mala fe y en el otro una ganancia debida al hecho de un tercero.

\section{Referencias}

Alcalde Silva, J., "El ejercicio de una actividad comercial en un determinado inmueble es suficiente para dar por establecida la posesión. La reivindicación procede también contra el poseedor material, sin que importe la carencia de cualquier inscripción a su respecto. Los bienes reservados revisten el carácter de propios de la mujer. La renuncia a los gananciales tiene cabida incluso cuando la mujer ha declarado cuál es la composición de la comunidad formada tras la disolución de la sociedad conyugal. Corte Suprema, sentencia de 5 de septiembre de 2017 (rol núm. 11.681-2017; CL/JUR/5819/2017)”, Revista Chilena de Derecho Privado, n. ${ }^{\circ} 29,2017,289-328$.

Alcalde Silva, J., "Las ‘acciones de dominio’ del artículo 898 del código civil”, en Gómez de la Torre, M., Hernández, G., Lathrop, F. y Tapia, M. (eds.), Estudios de derecho civil XIV, Santiago, Thomson Reuters, 2019, 267-300.

Alcalde Silva, J., "Los supuestos de tenencia reconocidos por el derecho. El concepto de título de mera tenencia o no traslaticio de dominio. La sociedad conyugal como título de tenencia suficiente para enervar una acción de precario ejercida por un tercero. La oponibilidad de la sociedad conyugal a terceros por 
parte de la mujer. El precario entre cónyuges. La legitimación activa de la acción de precario, especialmente cuando es ejercida por un usufructuario. La tutela del usufructuario. Corte Suprema, sentencia de 4 de mayo de 2015 (rol núm. 31.925-2014)", Revista Chilena de Derecho Privado, n. ${ }^{\circ} 26,2016,285-310$.

Alcalde Silva, J., "Notas para una relectura del sistema de propiedad raíz en el derecho chileno", en Domínguez Hidalgo, C. (ed.), Estudios sobre propiedad y posesión. Perspectiva chilena y latinoamericana, Santiago, Thomson Reuters, 2019, 33-64.

Alessandri Rodríguez, A., De la responsabilidad extra-contractual en el derecho civil chileno, 2. ${ }^{a}$ ed., Santiago, Ediar-Cono Sur, 1983.

Alferillo, P., "La 'mala fe'”, Universitas, n. ${ }^{\circ} 122,2011,441-482$.

Amunátegui Perelló, C., Código civil de Chile. Edición anotada, concordada y con fuentes, Valencia, Tirant lo Blanch, 2019.

Amunátegui Reyes, M. L., "Introducción”, en Bello López, A., Obras completas, XIII, Santiago, Pedro G. Ramírez, 1890, v-xliii.

Atria Lemaitre, F., "El sistema de acciones reales, parte especial: acción reivindicatoria, publiciana y del art. 915", Ius et Praxis, vol. 23, n. ${ }^{\circ} 2,2017,147-212$.

BANFI DEL Río, C., "Por una reparación integral del daño extracontractual limitada a los hechos dolosos o gravemente negligentes", Ius et Praxis, vol. 18, n. ${ }^{2}$, 2012, 3-32.

Barrientos Grandon, J., El código civil. Su jurisprudencia e historia. Edición crítica, concordada, comentada y anotada, I, Santiago, Thomson Reuters, 2016.

Barrientos Grandon, J., Las 'condictiones' en el código civil. El pago de lo no debido y otros supuestos de su procedencia, Santiago, Thomson Reuters, 2018.

Barros Bourie, E., Tratado de responsabilidad extracontractual, Santiago, Jurídica de Chile, 2006.

Bello López, A., Código civil de República de Chile, i, Caracas, Ministerio de Educación, 1954.

Bello López, A., Obras completas de don Andrés Bello, XII, Santiago, Imprenta de G. Ramírez, 1888. 
Boujon, F., Le droit commun de la France, Paris, Grangé, Cellot, 1770.

Bravo Lira, B., "En busca de los orígenes del Registro Conservatorio en Chile. Bello y el ABgB", en Sepúlveda Larroucau, M. A., Teoría general del derecho registral inmobiliario, Santiago, Metropolitana, 2014, 19-24.

Carbonnier, J., Droit civil, 19. a ed., Paris, Puf, 2000.

Casarino Viterbo, M., Manual de derecho procesal, iII, 6. a ed., Santiago, Jurídica de Chile, 2005.

Claro Solar, L., Explicaciones de derecho civil chileno y comparado, Ix, Santiago, Nascimento, 1934.

Corng, H., Derecho privado europeo, A. Pérez Martín (trad.), Madrid, Fundación Cultural del Notariado, 1996.

Connu, G., Droit civil. Introduction Les personnes. Les biens, 6. ed., Paris, Montchrestien, 1993.

Corral Talciani, H., Lecciones de responsabilidad civil extracontractual, 2. ed. Santiago, Thomson Reuters, 2013.

Cuesta SAenz, J. M., La acción publiciana, Madrid, Montecorvo, 1984.

Diez Schwerter, J. L., El daño extracontractual. Jurisprudencia y doctrina, Santiago, Jurídica de Chile, 2002.

Domínguez Águila, R., "Los límites al principio de reparación integral”, Revista Chilena de Derecho Privado, n. ${ }^{\circ}$ 15, 2010, 9-28.

Domínguez Águila, R., "Sobre el artículo 2316 inciso segundo del código civil y la acción contra el que recibe provecho del dolo ajeno", Revista de Derecho de la Universidad de Concepción, n. ${ }^{\circ} 225-226,2009,217-230$.

Domínguez Hidalgo, C., "El principio de reparación integral del daño: sus contornos", en Domínguez Hidalgo, C. et al. (ed.), Estudios de derecho civil viII, Santiago, Legal Publishing, 2013, 561-572.

Domínguez Hidalgo, C., "El principio de reparación del daño y su contenido: algunas consecuencias para el derecho chileno", en Departamento de Derecho 
Privado de la Universidad de Concepción (ed.), Estudios de Derecho civil v, Santiago, Legal Publishing, 2010, 671-685.

Elorriaga De Bonis, F., “'Compensatio lucri cum damno’. Las eventuales imputaciones a las indemnizaciones de perjuicios", Revista Anales Derecho UC, n. ${ }^{\circ} 7$, 2011, 117-149.

ESCRICHE Y MARTín, J., Diccionario razonado de legislación y jurisprudencia, nueva ed., Paris, Librería de Rosa Bouret y Cía., 1852.

Figueroa YÁÑEz, G. (coord.), Repertorio de legislación y jurisprudencia chilenas. Código civil y leyes complementarias, III, 3. a ed., Santiago, Jurídica de Chile, 1996.

Fueyo Laneri, F., Instituciones de derecho civil moderno, Santiago, Jurídica de Chile, 1990.

García Goyena, F., Concordancia, motivos y cometarios del código civil español, reimp. de la ed. de Madrid de 1852, Zaragoza, Cometa, 1974.

García Goyena, F. y Aguirre, J., Febrero ó librería de los jueces, abogados y escribanos, Madrid, I. Boix, VI, 1842.

García Mekis, B., "La naturaleza jurídica de la acción por provecho del dolo ajeno a la luz del denominado 'Caso Inverlink'", Actualidad Jurídica, n. 33, 2016, 339-357.

GuZmán Brito, A., Andrés Bello codificador. Historia de la fijación y codificación del derecho civil en Chile, Santiago, Universidad de Chile, 1982.

GuZmán Brito, A., Derecho privado romano, Santiago, Jurídica de Chile, 1996.

Guzmán Brito, A., "Dialéctica, casuística y sistemática en la jurisprudencia romana", Revista de Estudios Histórico-Jurídicos, n. ${ }^{\circ}$ 5, 1980, 17-31.

GuZMán Brito, A., La codificación civil en Iberoamérica. Siglos XIX y xx, Santiago, Jurídica de Chile, 2000.

Jestaz, P. y Jamin, C., La doctrina, P. Dufeu A. y D. Ejsmentewicz C. (trads.), Santiago, Rubicón, 2018.

KIPER, C., Juicio de acciones reales, Buenos Aires, Hammurabi, 2010. 
KIPER, C., Manual de derechos reales, 2. a ed., Córdoba, Rubinzal-Culzoni, 2018.

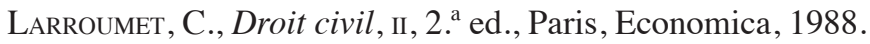

Lasso Gaite, F. J., Crónica de la codificación española, Iv, Madrid, Comisión General de Codificación, 1970.

Lira Urquieta, P., "García Goyena y el código civil chileno", en El código civil chileno y su época, Santiago, Jurídica de Chile, 1956, 75-98.

Malaurie, P. y Aynès, L., Les biens, 6. a ed., Paris, LgdJ, 2015.

Mejías Alonzo, C., Derecho real de domino y acción reivindicatoria. Posesión y acciones posesorias, Santiago, DER Ediciones, 2018.

Mery Berisso, R., "El código civil de la República de Chile y los tribunales de justicia", Anales de la Universidad de Chile, n. ${ }^{\circ} 103,1946,43-134$.

Muñoz Machado, S. (dir.), Diccionario del español jurídico, Barcelona, Espasa, 2016.

Peñailillo Arévalo, D., "Enriquecimiento sin causa. Principio de derecho y fuente de obligaciones", Revista de Derecho de la Universidad de Concepción, n. ${ }^{\circ} 200$, 1996, 7-40.

Peñailillo Arévalo, D., Los bienes. La propiedad y otros derechos reales, 2. ed., Santiago, Thomson Reuters, 2019.

Peñailillo Arévalo, D., "Expansiones y restricciones de la reivindicación en el derecho contemporáneo", en CÉsPEDES MuÑoz, C. (coord.), Estudios de derecho patrimonial, Santiago, Thomson Reuters, 2013, 47-83.

Pichonnaz, P., Les fondements romains du droit privé, Paris, LGDJ, 2008.

Pino Emhart, A., "La restitución de ganancias ilícitas y la acción de provecho del dolo ajeno", Ius et Praxis, vol. 22, n. ${ }^{\circ}$ 1, 2016, 227-270.

Pino Emhart, A., "Los supuestos de restitución de ganancias ilícitas en el derecho privado chileno", Revista Chilena de Derecho, vol. 46, n. ${ }^{\circ}$ 2, 2019, 373-398. 
Pizarro Wilson, C., "La acción de restitución por provecho del dolo ajeno", en PiZARro Wilson, C. (ed.), Estudios de derecho civil IV, Santiago, Legal Publishing, 2009, 679-688.

Planiol, M. y RiPert, G., Traité pratique de droit civil français, III, 2. ${ }^{a}$ ed., Paris, LGDJ, 1952.

Pothier, R. J., Pandectae Justinianeae in novum ordinem Digestae, i, nueva ed., Lyon, Bernuset et Cie., 1782.

Pothier, R. J., Traité du droit du domaine de propriété, I, Paris, Orleans, Debure, Veuve Rouzeau-Montaut, 1782.

Pothier, R. J., Tratado del derecho de dominio de la propiedad, M. Deó (trad.), Madrid y Barcelona, Librería de V. Suárez-Librería de J. Llordachs, 1882.

Rodríguez-Rosado, B., "La equivalencia de la escritura a la entrega y el valor de la tradición instrumental”, en Díez-Picazo, L. (coord.), Estudios jurídicos en homenaje al Profesor José María Miquel, Cizur Menor, Aranzadi-Thomson Reuters, 2014, II, 813-2831.

Rodríguez-Rosado, B., "Protección de los terceros adquirentes y de los acreedores en los diversos sistemas transmisivos: un intento de valoración", Revista Crítica de Derecho Inmobiliario, $\mathrm{n} .^{\circ} 733,2012,2645-2671$.

Rogel Vide, C., Alcolado Chico, M. T. y de Lamo Merlini, O., "Vindicar y reivindicar", Foro, nueva época, n. ${ }^{\circ}$ 1, 2005, 45-78.

Romero Seguel, A., Curso de derecho procesal civil, i, 3. a ed., Santiago, Thomson Reuters, 2017.

Salinas Araneda, C., "Notas en torno a las actas de los proyectos de código civil chileno", Revista de Derecho de la Pontificia Universidad Católica de Valparaíso, . $^{\circ} 1,1977,33-41$.

SAn Martín NeIRA, L., La culpa de la víctima en la responsabilidad civil, Santiago, DER Ediciones, 2018.

Saucedo, R., "Acciones reales", en Gurfinkel De Wendy, L., Derechos reales, I, Buenos Aires, Abeledo Perrot, 2016, 1299-1371. 
Schiele Manzor, C., “Artículo 894 del código civil: ¿prueba de mejor derecho?”, en Domínguez Hidalgo, C. (ed.). Estudios sobre propiedad y posesión. Perspectiva chilena y latinoamericana, Santiago, Thomson Reuters, 2019, 83-104.

ScIumè, A., s.v. "Rivendicazione (dir. intermedio)", en Enciclopedia del diritto, XLI, Milano, Giuffrè, 1989, 29-49.

Selman Nahum, A., "Algunas consideraciones sobre el precario y la naturaleza jurídica del precarista”, Ius et Praxis, vol. 24, n. ${ }^{\circ} 2,2018,341-392$.

Sepúlveda Larroucau, M. A., Teoría general del derecho registral inmobiliario, Santiago, Metropolitana, 2014.

Stitchrin Branover, D., El mandato civil, 3. a ed., Santiago, Jurídica de Chile, 1975.

TAPIA SuÁrez, O., De la responsabilidad civil en general y de la responsabilidad delictual entre contratantes, 2. a ed., Santiago, LexisNexis, 2006.

Terré, F. y Simler, P., Droit civil. Les biens, 9. a ed., Paris, Dalloz, 2014.

The American Law Institute, Restatement of the Law (Third) Restitution and Unjust Enrichment, Saint Paul, MN, The American Law Institute, 2011, II.

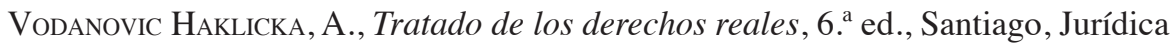
de Chile, 2011.

ZÁrate González, S., Tratado de derecho inmobiliario registral, Santiago, Metropolitana, 2019. 